\title{
Comparison of three methods for measuring heavy metals in calcareous soils of Iran
}

\author{
Karim Shahbazi ${ }^{1} \cdot$ Mehdi Beheshti $^{2}$
}

Received: 19 July 2019 / Accepted: 25 October 2019 / Published online: 4 November 2019

(c) Springer Nature Switzerland AG 2019

\begin{abstract}
The exact estimation of the heavy metals concentration in different soils is very important for determining the degree of soil contamination. This study was designed to determine the ability to extract heavy metals ( $\mathrm{As}, \mathrm{Cd}, \mathrm{Co}, \mathrm{Cr}, \mathrm{Cu}, \mathrm{Mn}, \mathrm{Ni}$, $\mathrm{Pb}, \mathrm{V}$ and $\mathrm{Zn}$ ) in calcareous soils using standard methods of digestion (ISO 14869-1, ISO 11466 and EPA 3050B) and the effect of lime on their extraction. In this study, 15 different soils with a wide range of chemical and physical properties and heavy metal concentrations and two reference materials were used. The results showed the percentage recovery in the reference material analyzed for the ISO 14869-1 method is between 94 and $107.8 \%$, for the ISO 11466 method is between 90.3 and $101.7 \%$ and for the EPA 3050B method varied between 84.6 and $105.9 \%$. The results showed that the recovery rate in the ISO 14869-1 method is better than the other methods (5\% average for all elements). The results of natural soils were compared with total digestion method ISO 14869-1, and the efficiency of Cd extraction by ISO 11466 was between 61.25 and $97.12 \%$. The extraction efficiency for As varied between 60.39 and $96.64 \%$. The extraction efficiency for the Co, $\mathrm{Cr}, \mathrm{Cu}, \mathrm{Mn}, \mathrm{Ni}, \mathrm{Pb}, \mathrm{V}$ and $\mathrm{Zn}$ elements was, respectively, between 71.2-96, 64.53-97.8, 66.07-96.3, 76.54-99.25, 79.3-100, 79.3-97.69, 73.43-95.30, and 73.7-99.9\%. The extraction efficiency of Cd by the EPA 3050B method was between 60.25 and $96.34 \%$. The extraction efficiency for As varied between 37.61 and $97.72 \%$. The extraction efficiency for the $\mathrm{Co}, \mathrm{Cr}$, $\mathrm{Cu}, \mathrm{Mn}, \mathrm{Ni}, \mathrm{Pb}, \mathrm{V}$ and $\mathrm{Zn}$ elements varied between 46.32-72.46, 47.61-71.66, 44.84-86.55, 49.21-76.64, 76.95-96.73, $43.38-99.9,43.17-81.12$, and $45.83-72.69 \%$, respectively. Based on the results, the ISO 11466 (Aqua regia) method is suggested as a suitable method for environmental studies in calcareous soils. The results showed that lime percentage has no effect on the recovery of the elements in calcareous soils.
\end{abstract}

Keywords Heavy metals · Calcareous soils · Extraction efficiency · ISO $11466 \cdot$ EPA 3050B

\section{Introduction}

Heavy metals are considered as the main inorganic contaminants in the environment due to their negative impact on living organisms and their disordering of the environmental balance [3]. Heavy metals occur naturally in the environment with differences in their concentrations. However, the ecosystem has been influenced and polluted by heavy metals generated from anthropogenic sources such as the disposal of residues from fossil fuel combustion processes and from different branches of the metallurgical, mining, and chemical industries [2]. High levels of heavy metals in sediment and soil may enter the water, groundwater and plants, and enter the body of human and animals from the cycle. Therefore, the use of simple and precise methods for investigating heavy metals in environmental studies is important. Now, an accurate estimate of the concentration of heavy metals in soil and various ecosystems is a major challenge. So, varied digestion methods are used including: use of concentrated acids such as

$\triangle$ Mehdi Beheshti, m.beheshti@ut.ac.ir; Karim Shahbazi, kshahbazi@swri.ir| ${ }^{1}$ Soil and Water Research Institute, Agriculture Research Education and Extension Organization (AREEO), Tehran, Iran. ${ }^{2}$ Department of Soil Science, University of Tehran, Tehran, Iran. 
hydrofluoric acid (HF), hydrochloric acid $(\mathrm{HCl})$, nitric acid $\left(\mathrm{HNO}_{3}\right)$, perchloric acid $\left(\mathrm{HClO}_{4}\right)$ and sulfuric acid $\left(\mathrm{H}_{2} \mathrm{SO}_{4}\right)$. Different devices are used for digestion, such as beakers that are placed on a hot plate, digestion tubes in the digestion blocks and digestion vessels in microwave ovens [17]. Digestion methods, including conventional digestion and acid digestion by microwave, are widely used to prepare samples for spectroscopic analysis. Conventional methods are the use of open vessels that are extracted from the heat in the mixture of acids. The conventional methods have many advantages, such as relatively cheap and low cost devices, and reduce the need for advanced treatment of samples. However, the conventional digestion methods have a long time and different stages for analysis, and they are labor intensive, arduous and tedious and often contain high contamination potential [43]. High-sensitivity spectroscopy techniques such as flame atomic absorption spectroscopy (FAAS) and graphite furnace atomic absorption spectroscopy (GFAAS), inductively coupled plasma emission spectrometry (ICP-OES) and inductively coupled plasma mass spectrometry (ICP-MS) have been broadly applied to measure the concentration of heavy metals in environmental samples [43]. These techniques have a disadvantage that they first require the solid sample to be transformed into solution where the metal content is determined (Prichard et al. 1996). Among the reagents, $\mathrm{HCl}, \mathrm{HNO}_{3}$ and $\mathrm{HF}$ are the most widely used reagents to digest the calcareous soils [42]; $\mathrm{H}_{2} \mathrm{O}_{2}$ is used in some cases [10]. These reagents are generally used in environmental studies. $\mathrm{HCl}$ and $\mathrm{HNO}_{3}$ solubilize carbonates and phosphates, $\mathrm{H}_{2} \mathrm{O}_{2}$ and $\mathrm{HNO}_{3}$ oxidize organic matter, and $\mathrm{HF}$ degrades the structure of aluminosilicates. Most studies emphasize that having complete digestion, the use of HF is necessary to break silicates [35]. Soil treatments with HF and $\mathrm{HClO}_{4}$ provide satisfactory results for the decomposition of both organic and mineral sections in the soil. The hydrofluoric acid, through the reaction of $\mathrm{F}$ with $\mathrm{Si}$, and the formation of $\mathrm{SiF}_{4}$, with strong acid when it is heated, is a volatile compound and decomposes silicates. $\mathrm{HClO}_{4}$ is also useful to eliminate the excess $\mathrm{HF}$ in the sample. However, long-term use of $\mathrm{HF}$ is dangerous and not recommended for routine and common analyses [52].

In studies, recovery for calcareous certified reference material when used with HF has been reported very low (less than $45 \%$ ) to very high (more than 173\%) depending on the element $[1,42]$. Therefore, using HF may be suitable for some elements and not acceptable for some other elements. Method 3050B is considered as a conventional method because this method is performed in the open system and the elements are extracted with nitric acid and hydrochloric acid using a thermal source. This method has a disadvantage in this way that the atmospheric pollution risk and waste of elements are most volatile, such as mercury [4]. Moreover, it should be noted that the 3050B method is not a complete digestion because its recovery is not $100 \%$ [44]. Simplicity and adaptability as a common and routine procedure have resulted in the wide use of the aqua regia method to determine amount of $\mathrm{Cd}, \mathrm{Cr}, \mathrm{Cu}, \mathrm{Ni}$, $\mathrm{Pb}$ and $\mathrm{Zn}$ elements in contaminated soils and sediments $[17,31]$. The Aqua regia method or ISO 11466 is used to extract the recoverable amounts of heavy metals in soils and provides an estimation of the maximum availability of these metals for the plant. The remaining metals that are not released with Aqua regia are the bound part to the silica mineral fraction, and it is assumed that the estimation of the mobility and behavior of that element is not important [37]. Nitric acid reacts with concentrated hydrochloric acid and produces Aqua regia: $3 \mathrm{HCl}+\mathrm{HNO}_{3} \gg \gg 2$ $\mathrm{H}_{2} \mathrm{O}+\mathrm{NOCl}+\mathrm{Cl}_{2}$. However, in carbonate-rich materials, a significant amount of $\mathrm{HCl}$ is used to neutralize lime. Under such circumstances, the correct formation of Aqua regia is doubtful (ISO 11466 [19]). This method is used to adjust the estimation of the effect of soil amendments such as sewage sludge on the environment in many countries $[25,30]$. Currently, many methods are used to quantify the amount of heavy metals in the soil, which requires examining the sample in a solvent form [48]. However, there is no international agreement on the unique digestion method that enables us to interpret the results in the same form in different parts of the world [38]. On the other hand, it is important to know how many elements in the soil are extracted by ISO 11466 and EPA 3050B methods compared to the total digestion method [38]. Studies show that there is a difference between digestibility and inappropriate yield in calcareous soils [29]. The accuracy of different digestion methods is variable in determining the concentration of total heavy metals in terms of the type of metal and soil properties [11]; therefore, first, a wide range of chemical and physical properties and the chemical of contaminated soils must be selected and different methods of digestion applied to determine the concentration of total heavy metals after determining the type of contamination. The total concentration of these metals indicates the dispersion and contamination level compared to the world standard level. The main objectives of this research include: (1) comparing three standard methods of ISO 14869-1, ISO 11466 and EPA 3050B in order to determine the concentration of 10 heavy elements (arsenic, cadmium, cobalt, chromium, copper, manganese, nickel, lead, vanadium and zinc) using two certified reference materials and 15 natural soil samples, (2) measuring the effect of soil properties, particularly lime, on the recovery percentage of heavy metals and (3) recommending the most proper and practical method depending on the type of element, digestibility and objective to measure the given elements. 


\section{Materials and methods}

\subsection{Area of study}

Soils with different physical and chemical properties and different land use and heavy metal contaminants were selected. Soil samples were collected from the of East Azerbaijan, Kurdistan, Zanjan, Arak, Qom, Alborz, Semnan and Khorasan Razavi provinces (Fig. 1). The focus was on the areas with the possibility of contamination.

\subsection{Collecting and preparing the soil}

Fifteen soil samples were collected from depths of 0-15 cm from different provinces. The soil samples were dried at room temperature and passed through a sieve of $2 \mathrm{~mm}$. Soil texture tested by hydrometer method [9], $\mathrm{pHs}, \mathrm{ECe}$ in soil saturation extract [14] soil organic matter by oxidation method with potassium dichromate [57] and lime by calcimeter method [27].

\subsection{Reagents}

Suprapure acids were provided by Merck company: $\mathrm{HCl}$ (37\% W/V), $\mathrm{HNO}_{3}(65 \% \mathrm{~W} / \mathrm{V}), \mathrm{HF}(40 \% \mathrm{~W} / \mathrm{V})$ and $\mathrm{HClO}_{4}$ (70\% W/V) (Suprapure, Merck). The lime $\left(\mathrm{CaCO}_{3}\right)$ used was also purchased from Merck Company. The calibration of the equipment's was performed with standard tetrazole (Merck) solutions containing $1 \mathrm{~g} \mathrm{I}^{-1}$ from the element for device analysis. High-purity water (electrical conductivity $<10 \mathrm{M} \Omega$ ) was used. All glass containers used were placed in $10 \%$ nitric acid overnight and then washed with distilled water.

\subsection{Digestion methods}

\subsubsection{ISO 14869-1}

Samples of $0.5 \mathrm{~g}$ were carefully weighed in polytetrafluoroethylene containers, and $5 \mathrm{ml}$ of concentrated $\mathrm{HNO}_{3}$ was added. The container was placed on a hot plate at $150^{\circ} \mathrm{C}$ and heated it until the volume of the solution reached about $1 \mathrm{ml}$ and then cooled to room temperature. This step repeated more than twice to ensure complete oxidation of soil organic
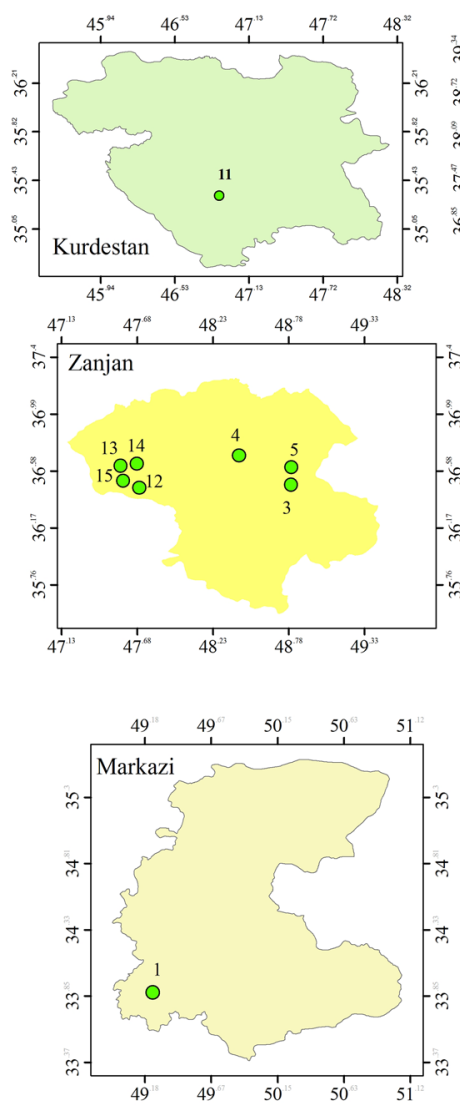
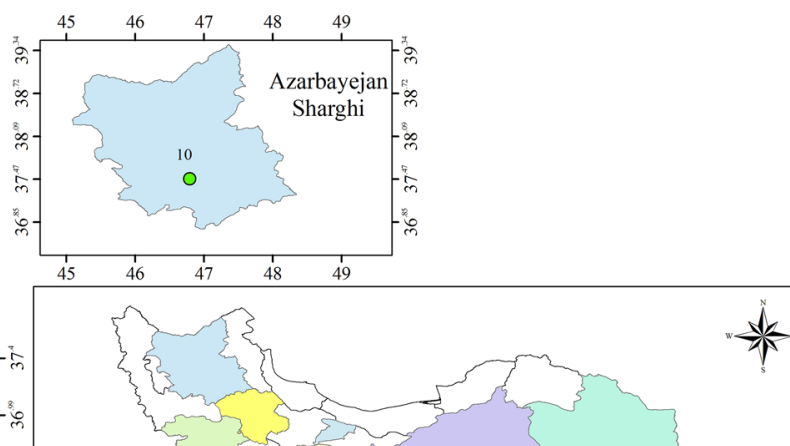

部
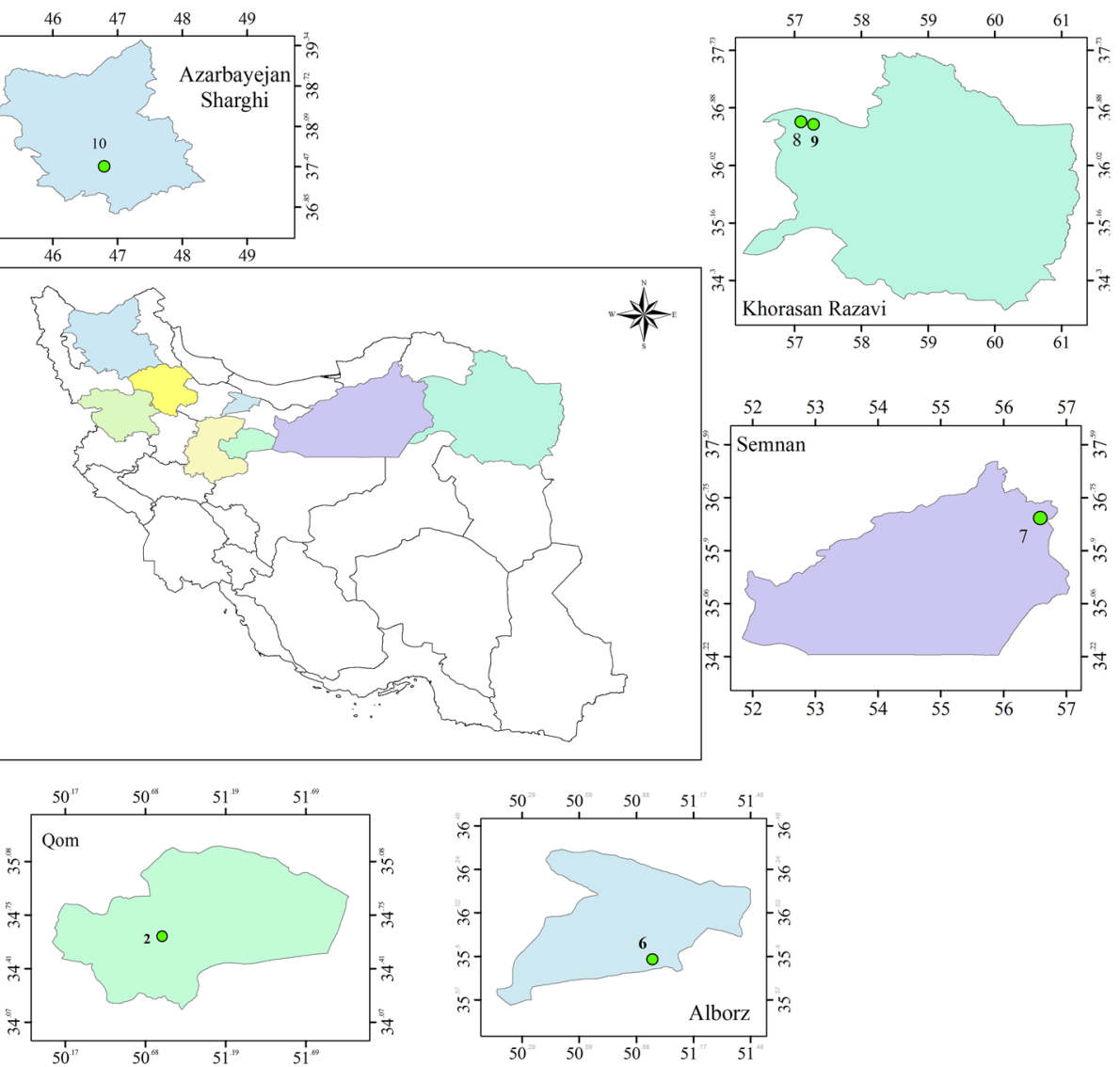

Fig. 1 Map of sampling points from the different province of Iran 
matter. After cooling, $5 \mathrm{ml}$ of $\mathrm{HF}$ and $1.5 \mathrm{ml}$ of $\mathrm{HClO}_{4}$ were added. The mixture was placed on a hot plate and heated up until the vapor perchloric acid and silicon tetrafluoride $\left(\mathrm{SiF}_{4}\right)$ were stopped. This step was repeated more than once. After cooling, $5 \mathrm{ml}$ of distilled water and $2 \mathrm{ml}$ of concentrated $\mathrm{HCl}$ were added and heated at low temperature to dissolve the remaining sediment. After cooling to room temperature, the sample was filtered in a $50-\mathrm{ml}$ volumetric flask and distilled water was added up to $50 \mathrm{ml}$ and stored in $4^{\circ} \mathrm{C}$ temperature for further analysis (ISO 14869-1 2001) [20].

\subsubsection{ISO 11466}

Soil samples of $3 \mathrm{~g}$ were carefully weighed and transferred to the digestion tubes. At first, the pretreatment step was carried out at room temperature for $16 \mathrm{~h}$ with $28 \mathrm{ml}$ of mixture (1:3) of 12 molar $\mathrm{HCl}$ and 17 molar $\mathrm{HNO}_{3}$ to slowly oxidize soil organic matter. Then, the mixture was connected to the reflux system and increased the heat to maintain reflux flow and continued reflux for $2 \mathrm{~h}$. After cooling to room temperature, the mixture was filtered to $100 \mathrm{ml}$ volumetric balloon with a filter paper without ash Whatman 41 and washed with $0.5 \mathrm{M}$ nitric acid and stored in polyethylene bottles at $4{ }^{\circ} \mathrm{C}$ for analyses (ISO 11466 1995) [19].

\subsubsection{EPA 3050B}

A method recommended by Environmental Protection Agency (EPA 3050B) was used as the conventional acid digestion method. Briefly, $1 \mathrm{~g}$ of soil samples was placed in a 250-ml flask for digestion. In the first step, $10 \mathrm{ml}$ of $\mathrm{HNO}_{3}(1: 1)$ was added to the sample and mixed then covered with watch glass in the digestion flask. The sample was refluxed without boiling for 10 to $15 \mathrm{~min}$ at $95 \pm 5^{\circ} \mathrm{C}$. After cooling, $5 \mathrm{ml}$ of concentrated $\mathrm{HNO}_{3}$ was added and refluxed for $30 \mathrm{~min}$. this process was continued until the other brown vapors were removed from the sample. Using a watch glass, the sample was heated at boiling point of $95 \pm 5^{\circ} \mathrm{C}$ and the solution was allowed to evaporate and the solution volume was reduced to about $5 \mathrm{ml}$. After cooling, slowly and without waste, $10 \mathrm{ml}$ of $30 \% \mathrm{H}_{2} \mathrm{O}_{2}$ was added and heated. Then, the sample was heated with $10 \mathrm{ml} 37 \% \mathrm{HCl}$ at $95^{\circ} \mathrm{C}$ for $15 \mathrm{~min}$. The extract obtained was filtered through a $0.45-\mu \mathrm{m}$ membrane paper, diluted to $100 \mathrm{ml}$ with deionized water and stored at $4^{\circ} \mathrm{C}$ for analyses. The total extraction process lasted for 180-200 $\mathrm{min}$ (USEPA 3050B) [55].

\subsection{Assessing the effect of lime percent on heavy metal recovery in Aqua regia media (ISO 11466)}

In order to assess the effect of lime on the formation of the Aqua regia media and the decrease in recovery of elements in the presence of lime, certain amount of lime (Merck) was added to the reference material of METRA$N A L^{\mathrm{TM}} 34$ so that the concentrations of 10,20,30, 40 and $50 \%$ lime were obtained. Then, the amount of heavy metals measured by ISO 11466.3 method and the percentage recovery of the elements were calculated.

\subsection{Heavy metal analysis}

Concentrations of $\mathrm{As}, \mathrm{Co}, \mathrm{Cr}, \mathrm{Cu}, \mathrm{Mn}, \mathrm{Ni}, \mathrm{Pb}, \mathrm{V}$ and $\mathrm{Zn}$ in final solutions digested with ICP Perkin Elmer Optima 2100 DV (USA) and Cd concentration with GFAAS Perkin Elmer $900 Z$ (USA) were measured. The operating conditions of the ICP and GFAAS devices are presented in Tables 1 and 2. The instruments were calibrated daily with standardized solutions. The analysis of the sample was performed only if the $R^{2}$ calibration curve was greater than 0.99 . A calibration check solution was prepared by another certified solution, and the calibration curves were checked after the initial calibration for every 10 samples. In the case of more than $\pm 10 \%$ deviation, the instruments were re-calibrated. To calculate the limit of detection the equipment, the concentration of heavy metals in the control solution of $2 \%$ nitric acid was read ten times. The limit of detection was calculated using $3 \sigma$, and the limit of quantitation by $10 \sigma$ [29]. The wavelength used for each element, $R^{2}$, calibration curve slope $(\mathrm{m})$, limit of detection and limit of quantitation for the instrument are presented in Table 3.

\subsection{Quality assurance and quality control}

Two certified reference materials (CRMs) including METRANAL ${ }^{\text {TM }} 33$ and METRANAL ${ }^{\text {TM }} 34$ purchased from Chinese METRANAL ${ }^{\mathrm{TM}}$ Company were digested in two

Table 1 Instrumental operating parameters for ICP-OES Perkin Elmer Optima 2100 DV

\begin{tabular}{ll}
\hline Parameter (unit) & Value \\
\hline RF power (w) & 1350 \\
Plasma flow $\left(I \mathrm{~min}^{-1}\right)$ & 15 \\
Auxiliary flow $\left(I \mathrm{~min}^{-1}\right)$ & 0.8 \\
Nebulizer model & Cross-flow \\
Nebulizer flow $\left(\mathrm{min}^{-1}\right)$ & 0.8 \\
Sample flow $\left(\mathrm{ml} \mathrm{min}^{-1}\right)$ & 2 \\
Gases & Argon and nitrogen \\
Share gas & Air \\
Plasma viewing & Axial \\
Read delay per replicate $(\mathrm{s})$ & 45 \\
Number of replicates & 2 \\
Measurement processing mode & Area \\
Calibration type & Zero intercept, linear \\
\hline
\end{tabular}


Table 2 Instrumental operating parameters for GFAAS Perkin Elmer $900 Z$

\begin{tabular}{ll}
\hline Parameter (unit) & $\mathrm{Cd}$ \\
\hline Argon flow $(\mathrm{ml} / \mathrm{min})$ & 250 \\
Sample volume $(\mu \mathrm{l})$ & 20 \\
Slit width $(\mathrm{nm})$ & 0.7 \\
Heating program temperature, ${ }^{\circ} \mathrm{C}($ ramp time $(\mathrm{s})$, hold time $(\mathrm{s}))$ \\
Drying 1 & $110(1,30)$ \\
Drying 2 & $130(15,30)$ \\
Ashing & $500(10,20)$ \\
Atomization & $1500(0,5)$ \\
Cleaning & $2450(1,3)$ \\
\hline
\end{tabular}

replications using three methods and analyzed for QA/ QC calculation. Table 6 shows the recovery of heavy metals in two certified reference materials, which are digested by three methods. For each digestion method, two blank samples were taken and their amount was adjusted. To calculate the methods' limit of detection for digesting heavy metals' concentration in the blank sample, 10 times its reading and standard deviation $(\sigma)$ were calculated and the limit of detection was calculated using $3 \sigma$ and the limit of quantitation using $10 \sigma$ [29] (Table 5). Recovery percentage was calculated from the following equation.

Recovery $(\%)=\frac{\text { Measured value }\left(\frac{\mathrm{mg}}{\mathrm{kg}}\right)}{\text { Certified value }\left(\frac{\mathrm{mg}}{\mathrm{kg}}\right)} \times 100$

Extraction efficiency (EE), expressed in percentage, was obtained from the ratio of extracted element amounts using the partial digestion methods of
EPA3050B and ISO 11466 to the total digestion method of ISO 14869-1 [38].

\subsection{Statistical analysis}

SAS 9.2 software (SAS [18] was used to calculate mean, standard deviation and Pearson correlation coefficient ( $r$ ). Also, SigmaPlot 14.0 software was used to draw charts.

\section{Results and discussion}

\subsection{Physical and geochemical characteristics of soils}

Soil No. 1 is from Arak, which is sampled around the Lakan lead and zink mine. The geological formations of the region include Cretaceous sediments, alluvial fans, anhydrite, argillaceous limes, and major minerals include sphalerite ( $\mathrm{ZnS})$, gallon ( $\mathrm{PbS})$, anglesite $\left(\mathrm{PbSO}_{4}\right)$ and cerussite $\left(\mathrm{PbCO}_{3}\right)$ [58]. Soil No. 2 was sampled from the pasturages of Qom. Soil Nos. 3, 4 and 5 were sampled from arable, forest and pasturages in Zanjan, which included alluvial terraces and quaternary alluvial deposits [40]. Sample No. 6 obtained from soil and water research farm was artificially contaminated with cadmium and lead and was remained for four years in normal conditions to achieve a state of condition. Soil No. 7 was from Semnan, and 8th and 9th soils were collected from the chromite Feroomad mine in Khorasan Razavi. The units of rock in this area are made from ophiolitic units (Hazburiti, Serpentine, Gabbro and Donit) as well as volcanic and pyroclastic units with Neogene age and limestone of Cretaceous age. Chromites in the region are pedopharm chromite. Also acidic stones with structure of conglomerate, sandstone, tuff, tofite and acid agglomerates were found in this area. Chromite $\left(\mathrm{FeCr}_{2} \mathrm{O}_{4}\right)$, crocusite $\left(\mathrm{PbCrO}_{4}\right)$, millerite $(\mathrm{NiS})$, nickelite (NiAs) and brittle polyethylene (NiSb) are major regional
Table 3 Instrumental detection limits and Limit of Quantitation $\left(\mu \mathrm{g} \mathrm{I}^{-1}\right)$ for ICP Perkin Elmer Optima 2100 DV and GFAAS Perkin Elmer $900 Z$

\begin{tabular}{lllllll}
\hline Element & Wave Length $(\mathrm{nm})$ & $R^{2}$ & $\begin{array}{l}\text { Claib. Range used } \\
\left(\mathrm{mg} \mathrm{I}^{-1}\right)\end{array}$ & Slope & LOD & LOQ \\
\hline As & 193.696 & 0.9997 & 2 & 0.31 & 10 & 33 \\
$\mathrm{Cd}{ }^{*}$ & 228.80 & 0.996 & 0.005 & 0.059 & 0.2 & 0.7 \\
$\mathrm{Co}$ & 228.616 & 0.9997 & 2 & 13.04 & 0.85 & 2.80 \\
$\mathrm{Cr}$ & 267.716 & 0.9998 & 5 & 44.03 & 1.25 & 4.13 \\
$\mathrm{Cu}$ & 327.393 & 0.9999 & 2 & 71.25 & 0.97 & 3.2 \\
$\mathrm{Mn}$ & 257.610 & 0.9998 & 20 & 149 & 1.4 & 4.6 \\
$\mathrm{Ni}$ & 231.604 & 0.9998 & 2 & 11.52 & 1.32 & 4.37 \\
$\mathrm{~Pb}$ & 220.353 & 0.9994 & 2 & 1.34 & 3.2 & 10.56 \\
$\mathrm{~V}$ & 292.464 & 0.9998 & 5 & 3.53 & 3.6 & 11.88 \\
$\mathrm{Zn}$ & 206.200 & 0.9996 & 2 & 3.61 & 7 & 23.1 \\
\hline
\end{tabular}

The cadmium concentration was read by GFAAS and other elements with the ICP instrument 
minerals [6]. Soil Nos. 10 and 11 were sampled east Azarbaijan and Kurdistan province; soil origin of the area is made of sedimentary and volcanic deposits that contain yukonite $\left[\mathrm{Ca}_{7} \mathrm{Fe}_{12}{ }^{3+}\left(\mathrm{AsO}_{4}\right) 10(\mathrm{OH})_{20} 15 \mathrm{H}_{2} \mathrm{O}\right]$, arsenopyrite (FeAsS), orpiment $\left(\mathrm{As}_{2} \mathrm{~S}_{3}\right)$ and realgar $\left(\mathrm{As}_{4} \mathrm{~S}_{4}\right)$ [8], [24]. Soils Nos. 12-15 were sampled around the Anguran mine in Zanjan, located on Shist Anguran Formation. Anguran kansar consists of two parts. An initial sulfide fraction is composed primarily of sphalerite ( $\mathrm{ZnS})$, gallon $(\mathrm{PbS})$ and pyrite $\left(\mathrm{FeS}_{2}\right)$, and a secondary carbonate element derived from the sulfide alteration and the development of its substitution phenomenon is mainly composed of anglesite $\left(\mathrm{PbSO}_{4}\right)$, Cerussite $\left(\mathrm{PbCO}_{3}\right)$ and smithsonite $\left(\mathrm{ZnCO}_{3}\right)$ [32].

The range of clay content in soil samples was between 6 and $41 \%$, the lowest amount was related to Anguran lead and zinc mine in Zanjan, and the highest amount of clay related to pasturage in Zanjan. The variation of organic matter changes ranged from $0.03 \%$ to $2.87 \%$, the lowest amount was related to the sample of Qom, and the highest amount was in the pasturage area of Zanjan. The range of lime changes was between 2.21 and $61.2 \%$, with the highest amount of lime from sample 3 from arable region in Zanjan, which includes alluvial carbonate terraces and argillic limes. The $\mathrm{pH}$ value was from 6.3 to 8.2 , with high $\mathrm{pH}$ in most soils indicating limestone and alkalinity of the soil. The EC value was different from 0.39 to $46.3 \mathrm{dS} / \mathrm{m}$ (Table 4).

\subsection{Limit of detection and limit of quantification of methods}

The limit of detection and limit of quantitation for different digestion methods are presented in Table 5. The limit of detection (LOD) ranged from 0.8 to $12.79 \mu \mathrm{g} \mathrm{I}^{-1}$, and the limit of quantitation (LOQ) varied from 2.64 to $42.22 \mathrm{\mu g} \mathrm{I}^{-1}$. Both the limits of detection and quantification are comparable with that obtained by Sandroni and Smith [41] and Marin et al. [29]. Chemical Blank unlike analytical blank, the digestion processes are completely done and therefore the LOD and LOQ are higher in them. The amount of LOD and LOQ in the comparison of digestion methods for the elements ( $\mathrm{Cd}, \mathrm{Co}, \mathrm{Cr}, \mathrm{Co}, \mathrm{Pb}, \mathrm{Zn}, \mathrm{Mn}$ and $\mathrm{Fe}$ ) varied between 0.5-30 and 2-99 $\mu \mathrm{g} \mathrm{I}^{-1}$, respectively. [29].

\subsection{Recovery of digestion methods}

The recovery percentage of different digestion methods is presented in Table 6 for two reference materials, METRA$N A L^{\text {TM }} 33$ and METRANAL ${ }^{\text {TM }} 34$. The results of three methods of digestion with a certified amount in the reference material were acceptable in the most elements. The recovery range varied between 84.6 and $107.8 \%$. The recovery percentage in the ISO 14869-1 method, which uses HF and

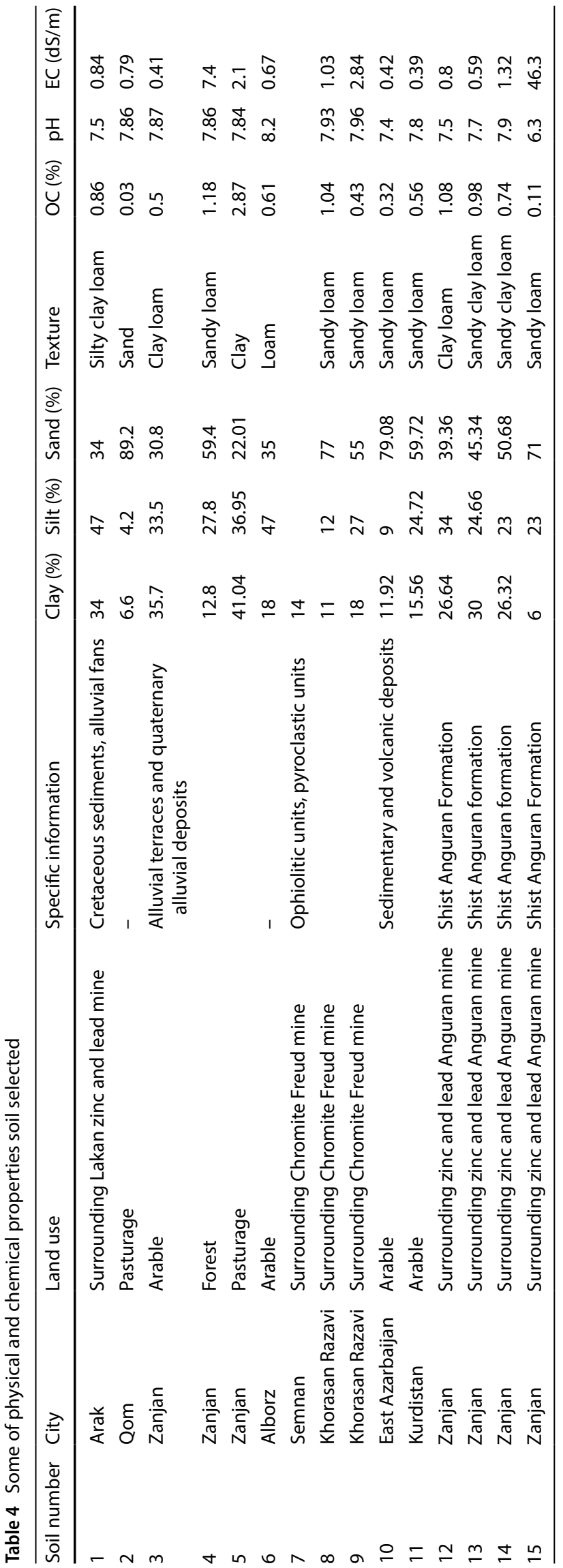


Table 5 Limit of detection and limit of quantitation $\left(\mu \mathrm{g} \mathrm{I}^{-1}\right)$ for digestion methods

\begin{tabular}{|c|c|c|c|c|c|c|}
\hline \multirow[t]{3}{*}{ Element } & \multicolumn{6}{|c|}{ Method } \\
\hline & \multicolumn{2}{|c|}{ ISO 14869-1 } & \multicolumn{2}{|c|}{ ISO 11466} & \multicolumn{2}{|c|}{ EPA 3050b } \\
\hline & LOD & LOQ & LOD & LOQ & LOD & LOQ \\
\hline As & 10.25 & 33.83 & 12.79 & 42.22 & 10.21 & 33.7 \\
\hline $\mathrm{Cd}^{*}$ & 0.03 & 0.1 & 0.04 & 0.12 & 0.02 & 0.06 \\
\hline Co & 0.89 & 2.93 & 0.9 & 3 & 0.98 & 3.24 \\
\hline $\mathrm{Cr}$ & 1.26 & 4.16 & 1.7 & 5.6 & 1.44 & 4.76 \\
\hline $\mathrm{Cu}$ & 1.29 & 4.27 & 1.08 & 3.55 & 1.2 & 3.95 \\
\hline$M n$ & 3 & 9.9 & 10 & 33 & 3.72 & 12.26 \\
\hline $\mathrm{Ni}$ & 1.42 & 4.69 & 1.51 & 4.97 & 1.79 & 5.92 \\
\hline $\mathrm{Pb}$ & 4.9 & 16.17 & 7.11 & 21.33 & 5.12 & 16.7 \\
\hline V & 3.62 & 11.94 & 4.1 & 13.45 & 6.48 & 21.38 \\
\hline $\mathrm{Zn}$ & 8.74 & 28.85 & 7.66 & 25.3 & 7.63 & 25.17 \\
\hline
\end{tabular}

* The cadmium concentration was read by GFAAS and other elements with the ICP instrument
$\mathrm{HClO}_{4}$ in the digestion process, was different between 94 and $107.8 \%$. The recovery percentage of this method was less than the certified value for all elements measured in the standard error range of the reference substance, with the exception of $\mathrm{Mn}$ in the reference material METRANAL ${ }^{\text {TM }}$ 34. Also, this method had overestimate in $\mathrm{As}, \mathrm{Cd}, \mathrm{Co}$ and $\mathrm{Cu}$. Adamo et al. [1] reported a recovery percentage in reference material CRM 141R when using $\mathrm{HF}$ for $\mathrm{Cd}$ and $\mathrm{Co}$ 115 and $147 \%$, respectively. The recovery percentage in calcareous material was reported when using HF for 118 , 118,126 and $129 \%$ digestion for $\mathrm{Cd}, \mathrm{Cr}, \mathrm{Cu}$ and $\mathrm{Ni}$ elements [42]. The recovery percentage in the NIST SRM 2704 reference material was different between 86 and $113 \%$ when it was digested with $\mathrm{HNO}_{3}-\mathrm{HClO}_{4}-\mathrm{HF}$ for $\mathrm{Cr}, \mathrm{Cu}, \mathrm{Ni}, \mathrm{Mn}$, $\mathrm{Pb}$ and $\mathrm{Zn}[50]$.

The recovery percentage in the ISO 11466 method was different between 90.3 and 101.7\%. All measured elements by this method have acceptable recovery percentages and were approved within the standard error range of the reference material, except for the $\mathrm{Cu}$ that was underestimated in the reference material METRANAL ${ }^{\mathrm{TM}} 33$ and underestimated in the reference material METRANAL ${ }^{\text {TM }} 34$ for $\mathrm{Cu}$ and $\mathrm{Co}$. $\mathrm{Cd}$ was overestimated in both reference materials. The recovery percentage of $\mathrm{Cu}, \mathrm{Ni}$ and $\mathrm{Pb}$ in reference substance IAEA-405 was 110, 105 and 114\%, respectively, with standard spikes to reference material [38]. The recovery percentage in reference material CRM $141 \mathrm{R}$ was reported to be $98,98,84,94,89,82$ and $101 \%$, respectively, according to ISO 11466 for $\mathrm{Cd}, \mathrm{Co}, \mathrm{Cr}, \mathrm{Cu}, \mathrm{Mn}$, $\mathrm{Pb}$ and $\mathrm{Zn}$ elements [29]. The recovery percentage of elements in the reference material LGC6187 was reported to be $110,104,103,89$ and $105 \%$, respectively, according to ISO 11466 for $\mathrm{Cr}, \mathrm{Ni}, \mathrm{Co}, \mathrm{Zn}$ and As [13]. The recovery percentage of elements was $96,103,95,84$ and $96 \%$, respectively, according to ISO 11466 for reference material CRM
142 for $\mathrm{Cd}, \mathrm{Co}, \mathrm{Ni}, \mathrm{Pb}$ and $\mathrm{Zn}$ elements and was reported to be $98,101,98,96$ and $102 \%$, respectively, for reference material CRM 143 [35].

The recovery percentage of the elements in the EPA 3050B method was different between 84.6 and $105.9 \%$. The measurement of $\mathrm{As}, \mathrm{Pb}$ and $\mathrm{Zn}$ was underestimated in the reference material of METRANAL ${ }^{\mathrm{TM}} 33$, and there was overestimate in $\mathrm{Cd}$ and $\mathrm{Cu}$. There was underestimate in the reference material METRANAL ${ }^{\text {TM }} 34$ in As measurement, and there was also overestimate in the Cu element. The recovery percentage in San Joaquin Soil-2709 Reference Material for $\mathrm{Cr}, \mathrm{Cu}, \mathrm{Pb}$ and $\mathrm{Zn}$ was reported to be 87.6, $62.1,36$ and $79.7 \%$, respectively, according to $3050 \mathrm{~B}$ and was $85.1,61.9,38.5$ and $85.5 \%$ for the reference material Estuarine Sediment-1646A, respectively [15]. The recovery percentage for the reference material NIST 2710 was 3050B for the elements $\mathrm{Cu}, \mathrm{Pb}, \mathrm{Zn}, \mathrm{Cr}$ and $\mathrm{Ni}$, respectively, and was $99,103,90,59$ and 49 was $97,107,97,49$ and $78 \%$, respectively, for the NIST 2711 [26].

\subsection{Assessing the effect of lime on heavy metal recovery in ISO 11466}

Figure 2 shows how different lime percentages affect the recovery of heavy metals in reference material METRA$N A L^{\text {TM }}$ 34. Lime with the consumption and neutralization of some $\mathrm{HCl}$ in the formation of the Aqua regia media causes the reduction in the recovery of the elements (ISO 11466 1995). As it is clear, the amount of lime has no effect on the recovery of most elements. In the $\mathrm{Cr}$ element, it reduces the recovery percentage that is within the limit of the standard error, and likely this difference was caused by instrument error. In the Cu element, the lime has been estimated to be higher, but this amount was more than estimated level within the standard error range of the 


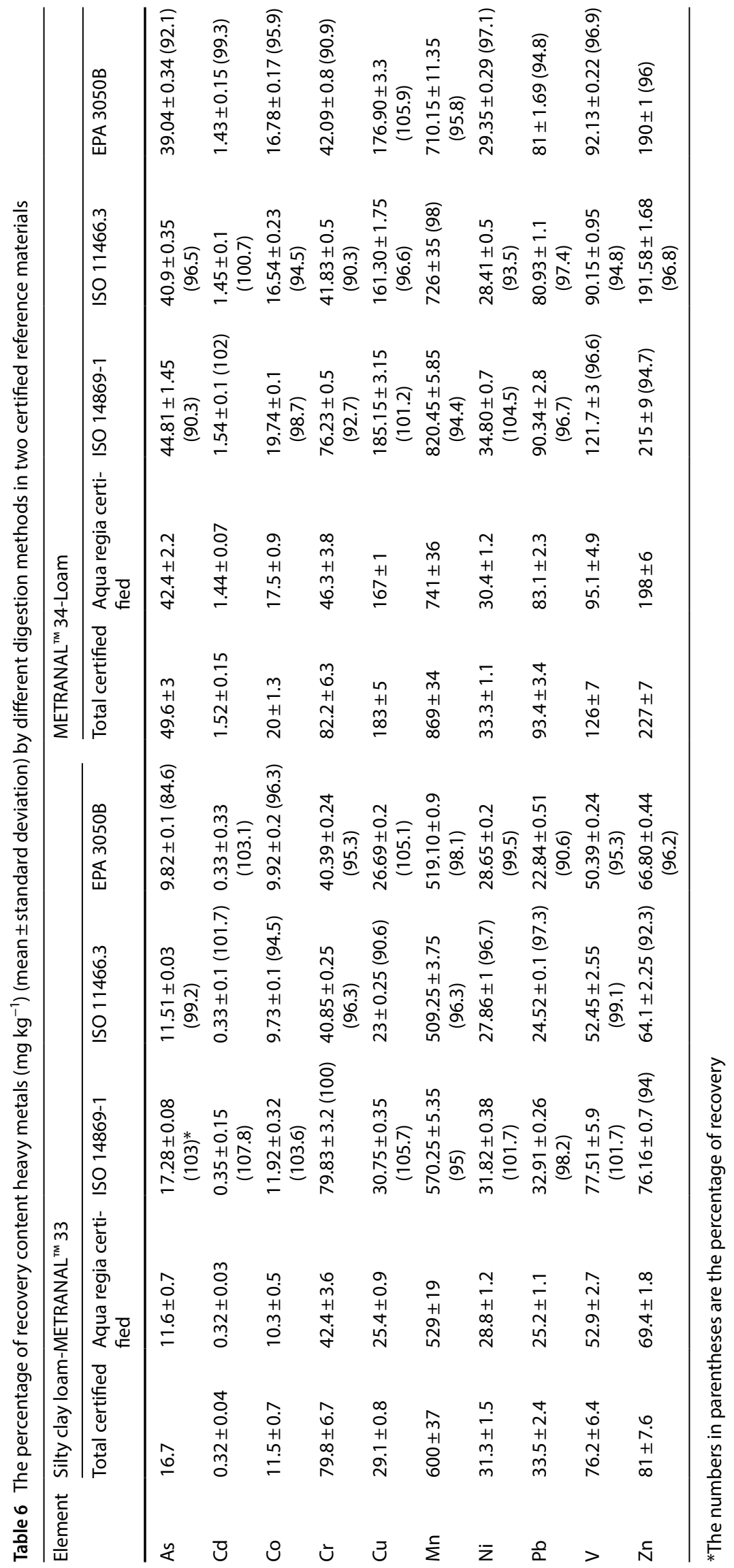



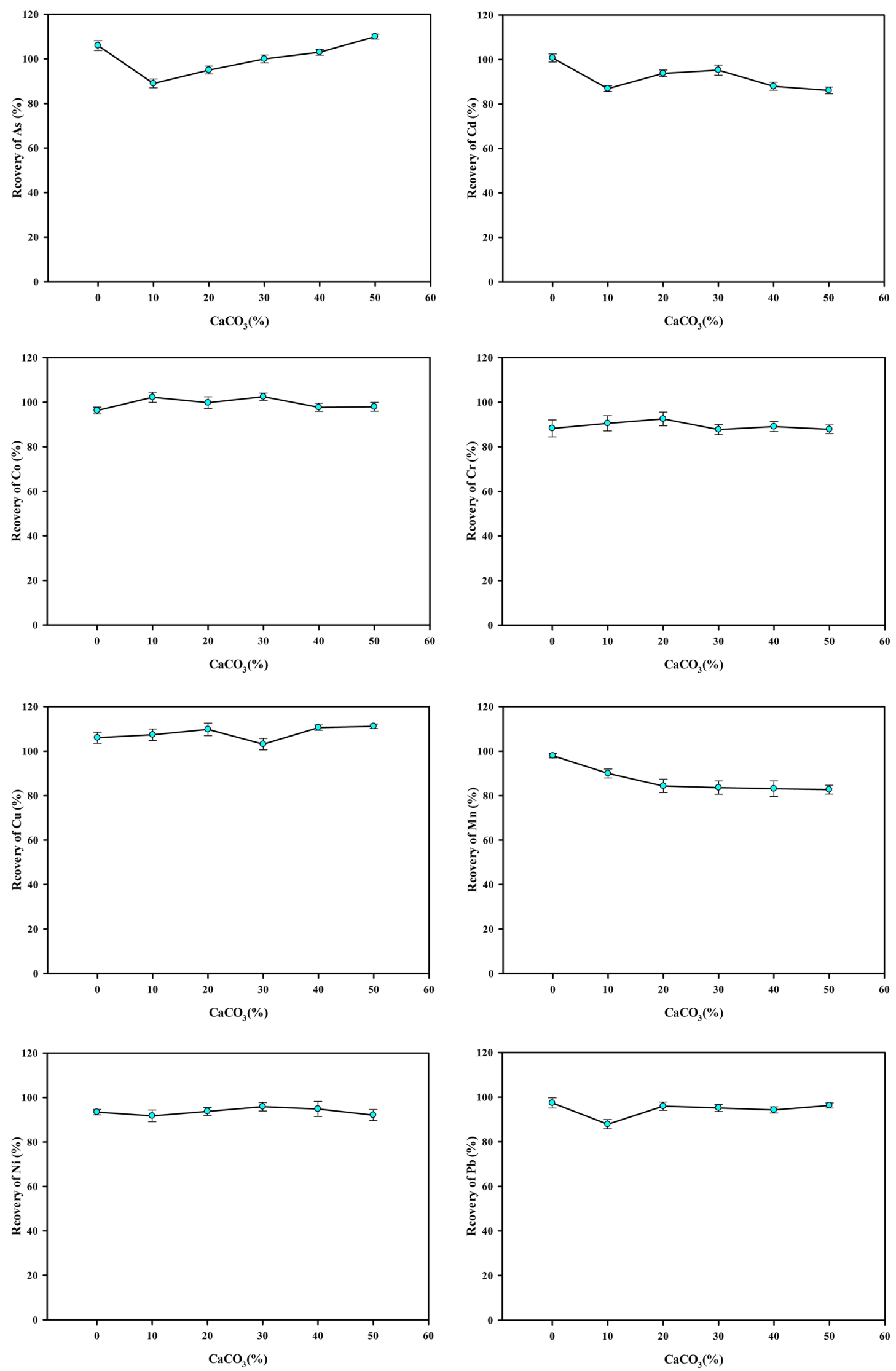

Fig. 2 Percentage of recovery heavy metals ( $\mathrm{As}, \mathrm{Cd}, \mathrm{Co}, \mathrm{Cr}, \mathrm{Cu}, \mathrm{Mn}, \mathrm{Ni}, \mathrm{Pb}, \mathrm{V}, \mathrm{Zn}$ ) in CRM METRANAL ${ }^{\mathrm{TM}} 34$ At various concentrations of lime 

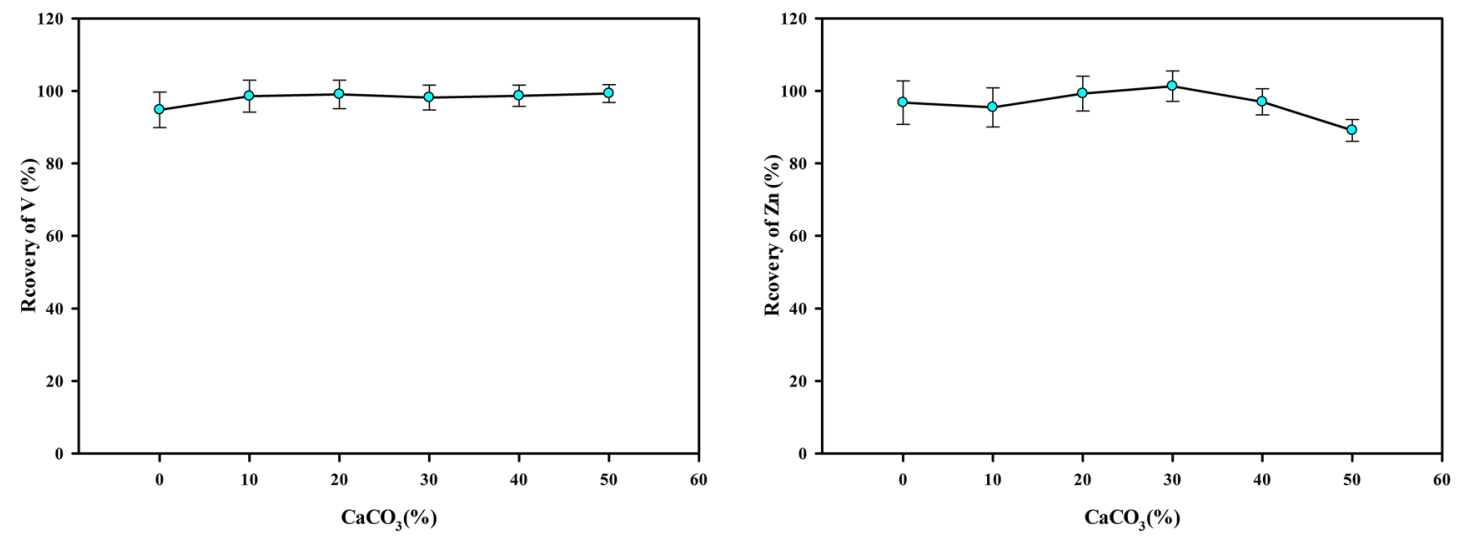

Fig. 2 (continued)

reference material. However, the $\mathrm{Mn}$ in quantities of more than $10 \%$ reduced the recovery rate and has no effect on recovery in the elements of $\mathrm{As}, \mathrm{Cd}, \mathrm{Co}, \mathrm{Ni}, \mathrm{Pb}, \mathrm{V}$ and $\mathrm{Zn}$.

\subsection{Comparison of digestion methods in natural soil samples}

Three methods of digestion were measured using 15 natural soils sampled from different regions of Iran with different physicochemical characteristics. We can examine the effects of different matrices and spectral interference in natural soil samples by these methods. Total digestion results according to ISO 14869-1 are shown in Table 7. As it is clear, using HF increases the ability to extract heavy metals from the soil. The total amount of As in soil samples was different between 4.09 and $1250 \mathrm{mg} / \mathrm{kg}$. The amount of As in soil Nos. 11 and 15 was higher than the limit, which is related to Kurdistan and Zanjan. The origin of arsenic is geological and is made of arsenopyrite minerals (FeAsS), enargite $\left(\mathrm{Cu}_{3} \mathrm{AsS}_{4}\right)$, orpiment $\left(\mathrm{As}_{2} \mathrm{~S}_{3}\right)$ and realgar $\left(\mathrm{As}_{4} \mathrm{~S}_{4}\right)$ in these areas. The total $\mathrm{Cd}$ content in soil samples is between 0.14 and $7.25 \mathrm{mg} / \mathrm{kg}$. The amount of Cd was high in soil No. 6 which has been artificially contaminated. The total Co content in soil samples was between 6.26 and $320.15 \mathrm{mg} /$ $\mathrm{kg}$. Cr content of all soils was between 26.11 and $564.4 \mathrm{mg} /$ $\mathrm{kg}$, and the $\mathrm{Cr}$ content was higher in soil Nos. 7, 8 and 9, which are related to the Feroomad chromite mine. This chromium is originated from chromite $\left(\mathrm{FeCr}_{2} \mathrm{O}_{4}\right)$ and crocoite $\left(\mathrm{PbCrO}_{4}\right)$ minerals. The amount of total $\mathrm{Cu}$ in all soils was between 33.98 and $184.35 \mathrm{mg} / \mathrm{kg}$ soil, and this high amount of $\mathrm{Co}$ in the soil No. 15 was related to enargite $\left(\mathrm{Cu}_{3} \mathrm{AsS}_{4}\right)$ mineral. The total amount of $\mathrm{Mn}$ is different between 223.9 and $5598.5 \mathrm{mg} / \mathrm{kg}$. Soil total Ni was different between 21.8 and $1131.1 \mathrm{mg} / \mathrm{kg}$ soil. The amount of $\mathrm{Ni}$ was high in soils 7, 8 and 9, which is likely related to millerite (NiS), niccolite (NiAs) and breithauptite (NiSb) minerals in the geological sediments of Feroomad mine area in
Semnan. The total amount of $\mathrm{Pb}$ in all soils was different from 13.1 to $5742 \mathrm{mg} / \mathrm{kg}$ soil. The $\mathrm{Pb}$ content in soil sample one was high, which was related to the Lacan lead and zinc mine, that contains galena $(\mathrm{PbS})$, anglesite $\left(\mathrm{PbSO}_{4}\right)$ and cerussite $\left(\mathrm{PbCO}_{3}\right)$ as the major regional minerals. High $\mathrm{Pb}$ content in sample 6 in Alborz is due to artificial contamination. The soil Nos. 12, 14 and 15 are related to the lead and zinc mine in Zanjan. The geological formations of the region consist of anglesite $\left(\mathrm{PbSO}_{4}\right)$ and cerussite $\left(\mathrm{PbCO}_{3}\right)$ minerals. The amount of vanadium of the soil was different from 35.26 to $328.45 \mathrm{mg} / \mathrm{kg}$. The amount of total $\mathrm{Zn}$ in all soils varied between 43 and $8657.25 \mathrm{mg} / \mathrm{kg}$. The amount of $\mathrm{Zn}$ was high in the soil 1, which was related to Markazi around the Lacan lead and zinc mine, which was originated from sphalerite ( $\mathrm{ZnS}$ ) mineral. $\mathrm{Zn}$ was high in soil Nos. 12, 14 and 15 sampled from Anguran lead and zinc mine in Zanjan, and the origin of zinc is from sphalerite $(\mathrm{ZnS})$ and smithsonite $\left(\mathrm{ZnCO}_{3}\right)$ minerals. Using a mixture of acids increases the digestion efficiency [54]. The mixture of $\mathrm{HCl}, \mathrm{HNO}_{3}, \mathrm{HClO}_{4}$ and $\mathrm{HF}$ acids dissolves most elements in the soils [51]. Using HF in soils results in the formation of Ca-F complex, which interferes with the analysis of the device. $\mathrm{HClO}_{4}$ and $\mathrm{H}_{3} \mathrm{BO}_{3}$ should be used to prevent forming the complex [36]. Hydrofluoric acid affects greatly the digestion process because it breaks down the structure of the silicates and increases the results $[35,43]$. However, using it can result in interference in a wide range of elements [1, 42]. Natural soil samples are more heterogeneous than reference materials, which can provide highly variable recovery values for metals due to different matrix effects [29].

Table 8 shows the results of heavy metals in 15 soil samples digested by ISO 11466. The efficiency of extraction of this method for As was different between 60.39 and $96.64 \%$. The efficiency of Cd extraction was between 61.25 and $97.12 \%$. The extraction efficiency was between 71.2-96, 64.53-97.8, 66.07-96.3, 76.54-99.25, 79.3-100, 


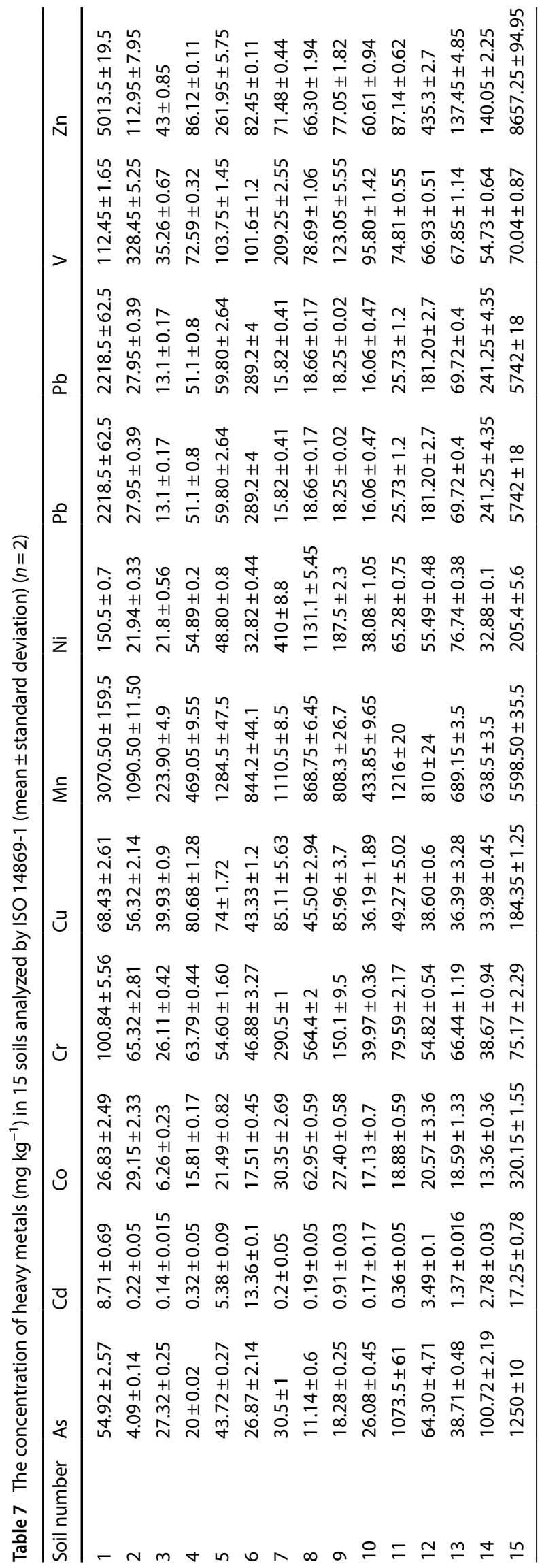

79.3-97.69, 73.43-95.3 and 73.7-99.9\%, respectively, for the $\mathrm{Co}, \mathrm{Cr}, \mathrm{Co}, \mathrm{Mn}, \mathrm{Ni}, \mathrm{Pb}, \mathrm{V}$ and $\mathrm{Zn}$ elements. Poor extraction efficiency of the elements in samples $5,3,1,13$, 12 and 14 is likely related to high clay content. The low extraction percentage in soils Nos. of 4, 5, 12, 8, 13 and 1 is related to high organic matter in the soil. Niskavawara et al. 1997 reported that the rest of the elements in the soil solution not released by the Aqua Regia method are often bonded to silicate minerals. However, this group of heavy silicate compounds has no importance to estimate mobility and usability. Vercoutere et al. [56] reported an Aqua regia digestion method as an effective and useful method to determine the concentration of heavy metals. The Aqua regia method may be used to measure $\mathrm{Cu}, \mathrm{Ni}$ and $\mathrm{Zn}$ in soils affected by human activities and therefore may be suitable to analyze regularly the heavy metal contamination in soils [16]. Manz et al. [28] used Aqua Regia to measure the content of $\mathrm{Cu}, \mathrm{Pb}$ and $\mathrm{Zn}$ agriculture soils in Germany. Twyman [54] reported that Aqua Regia solution is effective in dissolving sulfides, phosphates and many metals and alloys such as Pt, Au and Pd. Determining the releasing part with Aqua Regia provides valuable information on the long-term presence of heavy metals in the soil. In this regard, the latest methods of digestion introduced by Aqua Regia have been used to dissolve various compounds [7]. Berrow and Stein [5] reported that Aqua regia extracts more than $70 \%$ of $\mathrm{Cd}, \mathrm{Mn}$ and $\mathrm{Ni}$ from some sediment. Recovery ranging from $43 \%$ to $77 \%$ for $\mathrm{Cd}, \mathrm{Co}, \mathrm{Cr}, \mathrm{Cu}$, $\mathrm{Fe}, \mathrm{Mn}, \mathrm{Ni}, \mathrm{Pb}$ and $\mathrm{Zn}$ was reported according to $\mathrm{AGAL}-11$ reference sedimentation by Siaka et al. [46]. A study conducted by some researchers showed that extraction with Aqua regia resulted in the maximum recovery of acid-soluble elements [23] and resulted in recovery between $89 \%$ and $110 \%$ for some metals in soil and sediments [7]. Past work has shown that the use of Aqua regia for extraction may result in a low estimation of heavy metals amount such as $\mathrm{Co}, \mathrm{Cd}, \mathrm{Cr}$ and $\mathrm{Ni}$ up to $50 \%$ of the total amount $[45,53]$. The reasons for this low estimation can be the type of matrix and the strength of the Aqua regia solution, which cannot dissolve silicates, iron oxides and aluminum oxides, metals of which can form with these bonding compounds. Studies have shown that the efficiency of the Aqua regia extraction solution is different in different soils. For example, this value for $\mathrm{Cd}$ has been reported between 43 and $90 \%$ in various studies, which is consistent with the values obtained in this study (61-97\%). However, Sastre et al. [43] showed in their study that the difference between the total amount and the amount extracted with the Aqua regia solution cannot be considered as a general rule and may be highly affected by the studied element, the chemical composition of the matrix, organic matter and the solvent type used to extract all of the elements. $\mathrm{Ni}$ in the soil is with oxides and iron hydroxides that are not 


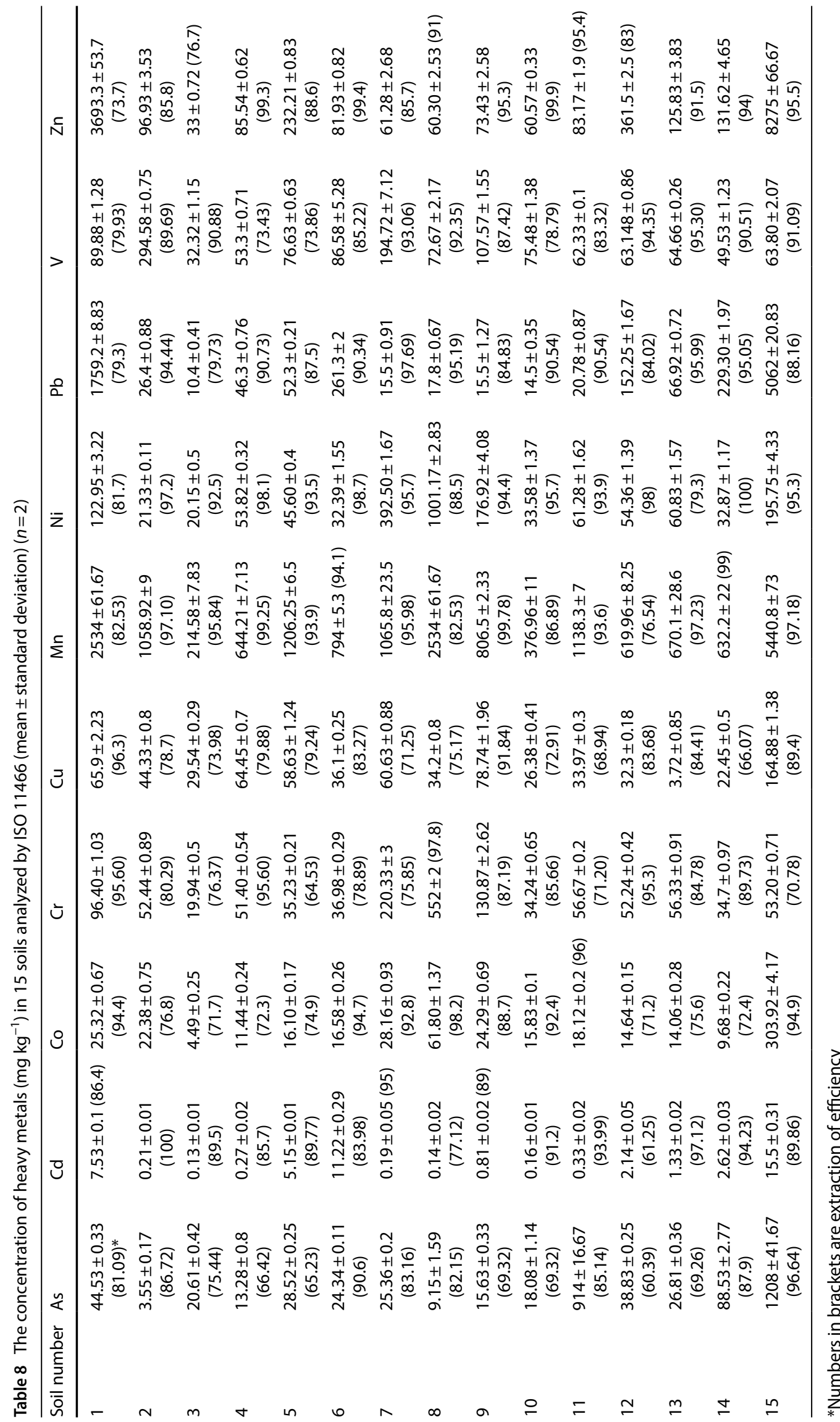


completely solved by the Aqua regia solution [45]. $90 \%$ of manganese, $\mathrm{Zn}, \mathrm{Cu}, \mathrm{Pb}$ and $\mathrm{Cd}$ of the entire soil can be extracted by the Aqua regia solution [12]. $95 \%$ of soil total zn, $\mathrm{Cu}, \mathrm{Ni}$ about $80 \%$ of soil total $\mathrm{Cd}$ and about $60 \%$ of soil total $\mathrm{Cr}$ can be extracted by Aqua regia [22,39].

Table 9 shows the amount of heavy metals in 15 soil samples obtained by the EPA 3050B method. The efficiency of extraction of this method for As was different between 37.61 and $97.72 \%$. The efficiency of $C d$ extraction was between 60.25 and $96.34 \%$. The extraction efficiency was different between 46.32-72.46, 47.61-71.66, 44.84-86.55, 49.21-76.64, 76.95-96.73,43.38-99.9, 43.17-81.12, and 45.83-72.69\%, respectively, for the $\mathrm{Co}, \mathrm{Cr}, \mathrm{Cu}, \mathrm{Mn}, \mathrm{Ni}, \mathrm{Pb}$, $\mathrm{V}$ and $\mathrm{Zn}$ elements. The low extraction efficiency of samples $5,3,1,13,12$ and 14 is likely caused by high clay content. The low extraction percentage in samples 5, 4, 12, 8,13 and 1 is related to the high organic matter content of the soil. Low estimation of Pb according to EPA 3050B method in soil No. 1 and Nos. 12-15 is related to the lead in lead sulfide $(\mathrm{PbS})$ form, which nitric acid causes oxidation of $\mathrm{PbS}$, that results in salt formation of $\mathrm{PbSO}_{4}$, which has low solubility and remains in sediment form. In contrast, $\mathrm{HCl}$ in the Aqua regia media tends to form a lead chloride complex $\left(\mathrm{PbCl}_{2}\right)$ in the ISO 11466 method, which is a soluble compound and easily extracted [38]. In general, the EPA 3050B was less effective than most of the elements in the ISO 11466 method. Peña-lcart et al. [38] reported that in six sediment samples examined by EPA 3050B and ISO 11466 , the extraction efficiency of $\mathrm{Co}, \mathrm{Ni}$ and $\mathrm{Pb}$ is higher in the ISO 11466 method. The extraction percentage was reported between $97-100 \%$ for $\mathrm{Cd}, \mathrm{Cr}, \mathrm{Ni}, \mathrm{Pb}$ and $\mathrm{Zn}$ in both soil samples and sewage sludge [47]. The EPA 3050B method has high efficiency in the extraction of $\mathrm{Cd}, \mathrm{Ni}, \mathrm{Co}$, $\mathrm{Pb}$ and $\mathrm{Zn}$ from soil [49].

\subsection{Correlation between Heavy Metals Concentration in Soil}

The result correlation between the concentrations of heavy metals is shown in Table 10. As it is clear, there is a strong and significant correlation between As-Co, As-Mn, $\mathrm{As}-\mathrm{Pb}$ and $\mathrm{As}-\mathrm{Zn}, \mathrm{Co}-\mathrm{Cd}, \mathrm{Co}-\mathrm{Cu}$, which is related to the geological origin of these metals. These metals are present in most geological formations in the structure of minerals. There is a positive and significant correlation between $\mathrm{Cr}$ and $\mathrm{Ni}$, which is likely due to these two elements in the geological formations in chromite $\left(\mathrm{FeCr}_{2} \mathrm{O}_{4}\right)$ and millerite (NiS) forms. There is a positive and significant correlation between $\mathrm{Cu}-\mathrm{As}, \mathrm{Cu}-\mathrm{Cd}, \mathrm{Cu}-\mathrm{Co}, \mathrm{Cu}-\mathrm{Mn}, \mathrm{Cu}-\mathrm{Pb}, \mathrm{Cu}$ and $\mathrm{Zn}$. There is a positive and significant correlation between manganese and $\mathrm{As}, \mathrm{Cd}, \mathrm{Co}, \mathrm{Pb}$ and $\mathrm{Zn}$ with coefficients of $0.69,0.8,0.89,0.97$ and 0.98 , respectively. There is a positive and significant relationship (0.98) between $\mathrm{Pb}$ and $\mathrm{Zn}$ which is caused by these two elements in Anguran geological formation in Zanjan and the Lakan lead and zinc mine in Markazi province, Iran, in the form of anglesite $\left(\mathrm{PbSO}_{4}\right)$, cerussite $\left(\mathrm{PbCO}_{3}\right)$, smithsonite $\left(\mathrm{ZnCO}_{3}\right)$ minerals. There is an insignificant negative relationship between $\mathrm{V}$ and most of the measured elements. There is a positive and significant correlation between $\mathrm{Ni}, \mathrm{Cu}, \mathrm{Cr}, \mathrm{Zn}$ and $\mathrm{Cd}$ in 295 soil samples analyzed in grassland, forests and agriculture soils in Ireland [33].

\subsection{Correlation between percentage of heavy metals recovery and soil characteristics}

Pearson correlation coefficient $(r)$ between extractable metals by two pseudo-total digestion methods including ISO-11466 and EPA 3050B and soil properties including percentage of clay, organic matter, $\mathrm{CaCO}_{3}, \mathrm{pH}$ and $\mathrm{EC}$, as well as the correlation coefficient between heavy metals (Tables 11 and 12) was used to predict the effect of soil features on the percentage of soil heavy metals recovery. Clay and soil organic matter has a negative with the extraction of heavy metals from the soil, but this is not significant for most of the elements. The percentage of clay has a negative and significant effect on the recovery of zinc extracted according to the ISO-11466 method. Also, the EPA 3050B method showed a negative and significant effect on nickel element retrieval. The amount of organic matter has a negative and significant effect on soil arsenic recovery in ISO 11466 and on the recovery of nickel in the EPA 3050B. Heavy metals bound with soil particles and have high tend to form a bond with soil organic matter, which causes reduction in its extraction by extracting solution extractor [54]. $\mathrm{CaCO}_{3}$ content is one of the most important factors that control the accumulation, mobility and bioavailability of heavy metals in arid soils [34].

The results showed that lime percentage had negative relationship with heavy metal extraction, but this effect was not significant for most of the elements except recovered Co by the ISO-11466 method, which is consistent with the results obtained in Sects. 3-4. There is a negative correlation between soil $\mathrm{pH}$ and $\mathrm{As}, \mathrm{Cd}, \mathrm{Co}, \mathrm{Cu}$, $\mathrm{Mn}, \mathrm{Pb}$ and $\mathrm{Zn}$. The $\mathrm{pH}$ of the soil keeps the metals in the soils through several mechanisms. Many of the adsorption sites in soil are $\mathrm{pH}$ dependent, i.e., Fe and $\mathrm{Mn}$ oxides, organic matter, carbonate and clay minerals [34]. Reducing the extraction of heavy metals by increasing soil $\mathrm{pH}$ might be explained by lowering solubility at high $\mathrm{pH}$ and decomposition of minerals and/or organic-mineral complexes. There is an insignificant and positive relationship in terms of the amount of heavy metals between the soil and soil EC, except for recovered zinc element using the EPA 3050B method, which is significant. There is a close relationship between the amount of metals extracted by EPA 


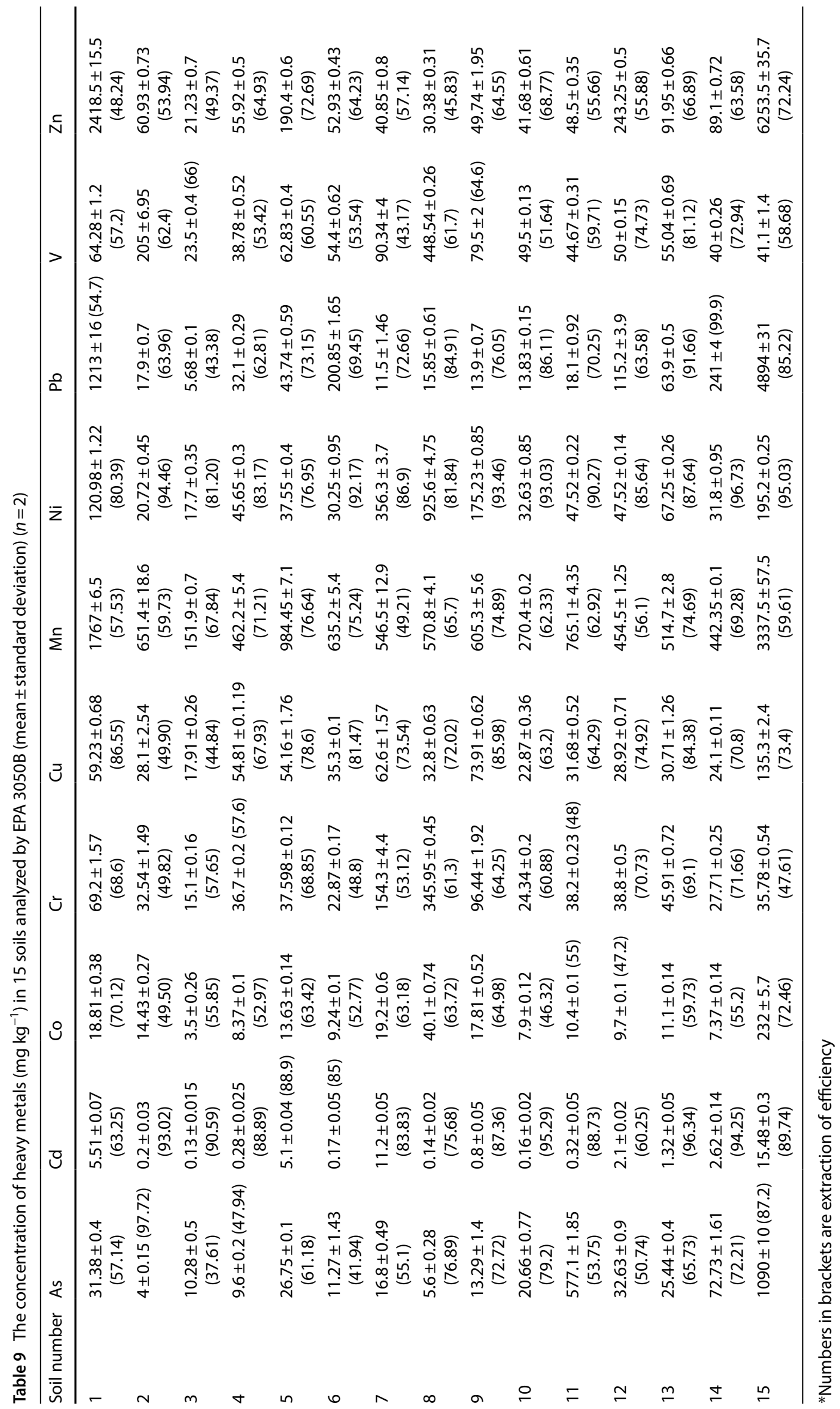


Table 10 Correlation coefficient $(r)$ of Pearson between heavy metal concentrations measured by ISO-14869-1

\begin{tabular}{lllllllllll}
\hline Parameter & $\mathrm{As}$ & $\mathrm{Cd}$ & $\mathrm{Co}$ & $\mathrm{Cr}$ & $\mathrm{Cu}$ & $\mathrm{Mn}$ & $\mathrm{Ni}$ & $\mathrm{Pb}$ & $\mathrm{V}$ & $\mathrm{Zn}$ \\
\hline $\mathrm{As}$ & 1 & & & & & & & & \\
$\mathrm{Cd}$ & 0.45 & 1 & & & & & & & \\
$\mathrm{Co}$ & $0.72^{* *}$ & $0.7^{* * *}$ & 1 & & & & & & \\
$\mathrm{Cr}$ & -0.13 & 0.07 & 0.07 & 1 & & & & & \\
$\mathrm{Cu}$ & $0.61^{*}$ & $0.78^{* *}$ & $0.87^{* *}$ & 0.02 & 1 & & & & \\
$\mathrm{Mn}$ & $0.69^{* *}$ & $0.8^{* *}$ & $0.89^{* *}$ & -0.03 & $0.85^{* *}$ & 1 & & & \\
$\mathrm{Ni}$ & -0.06 & 0.10 & 0.19 & $0.98^{* *}$ & 0.07 & 0.06 & 1 & & \\
$\mathrm{~Pb}$ & $0.67^{* *}$ & $0.76^{* *}$ & $0.92^{* *}$ & -0.10 & $0.83^{* *}$ & $0.97^{* *}$ & 0.01 & 1 & \\
$\mathrm{~V}$ & -0.21 & 0.09 & -0.09 & 0.11 & 0.07 & -0.01 & -0.002 & -0.14 & 1 \\
$\mathrm{Zn}$ & $0.61^{*}$ & $0.76^{* *}$ & $0.85^{* *}$ & -0.09 & $0.79^{* *}$ & $0.98^{* *}$ & 0.01 & $0.98^{* *}$ & -0.12 & 1 \\
\hline
\end{tabular}

${ }^{* *}$ Correlation is significant at the 0.01 level (2-tailed)

${ }^{*}$ Correlation is significant at the 0.05 level (2-tailed)

Table 11 Correlation coefficient $(r)$ of Pearson between chemical and physical properties of soil and percent recovery of heavy metals measured by ISO-11466 method

\begin{tabular}{|c|c|c|c|c|c|c|c|c|c|c|c|c|c|c|c|}
\hline Parameter & Clay (\%) & OC (\%) & $\mathrm{CaCO}_{3}(\%)$ & $\mathrm{pH}$ & $\mathrm{EC}$ & As & $\mathrm{Cd}$ & Co & $\mathrm{Cr}$ & $\mathrm{Cu}$ & $\mathrm{Mn}$ & $\mathrm{Ni}$ & $\mathrm{Pb}$ & V & $\mathrm{Zn}$ \\
\hline Clay (\%) & 1 & & & & & & & & & & & & & & \\
\hline OC (\%) & $0.64^{* *}$ & 1 & & & & & & & & & & & & & \\
\hline $\mathrm{CaCO}_{3}(\%)$ & $0.53^{*}$ & 0.20 & 1 & & & & & & & & & & & & \\
\hline $\mathrm{pH}$ & 0.26 & 0.24 & 0.38 & 1 & & & & & & & & & & & \\
\hline EC & -0.38 & -0.22 & -0.30 & $-0.86^{* *}$ & 1 & & & & & & & & & & \\
\hline As & -0.48 & $-0.6^{*}$ & -0.26 & -0.19 & 0.44 & 1 & & & & & & & & & \\
\hline $\mathrm{Cd}$ & -0.09 & -0.22 & 0.02 & 0.13 & 0.03 & 0.45 & 1 & & & & & & & & \\
\hline Co & -0.47 & -0.36 & $-0.73^{* *}$ & -0.22 & 0.22 & $0.57^{*}$ & 0.06 & 1 & & & & & & & \\
\hline $\mathrm{Cr}$ & 0.003 & -0.15 & -0.08 & 0.15 & -0.33 & -0.14 & -0.46 & 0.04 & 1 & & & & & & \\
\hline $\mathrm{Cu}$ & 0.12 & 0.04 & -0.41 & -0.33 & 0.33 & 0.05 & -0.13 & 0.15 & 0.20 & 1 & & & & & \\
\hline $\mathrm{Mn}$ & -0.30 & -0.12 & 0.19 & 0.21 & 0.19 & 0.45 & $0.57^{*}$ & -0.004 & -0.36 & -0.26 & 1 & & & & \\
\hline $\mathrm{Ni}$ & -0.39 & -0.17 & 0.12 & 0.07 & 0.12 & 0.15 & -0.08 & -0.17 & -0.26 & -0.41 & 0.10 & 1 & & & \\
\hline $\mathrm{Pb}$ & -0.42 & -0.10 & -0.22 & 0.10 & 0.01 & 0.12 & 0.19 & -0.03 & 0.06 & -0.34 & 0.47 & 0.12 & 1 & & \\
\hline V & -0.14 & -0.48 & 0.09 & -0.12 & 0.09 & 0.29 & -0.18 & -0.02 & 0.30 & -0.07 & 0.08 & -0.11 & 0.30 & 1 & \\
\hline $\mathrm{Zn}$ & $-0.56^{*}$ & -0.08 & -0.32 & -0.04 & 0.26 & 0.18 & 0.29 & 0.23 & -0.22 & -0.20 & 0.42 & 0.41 & 0.39 & -0.23 & 1 \\
\hline
\end{tabular}

** Correlation is significant at the 0.01 level (2-tailed)

${ }^{*}$ Correlation is significant at the 0.05 level (2-tailed)

3050B and ISO 11466 methods with physical and chemical properties of soil, and as a result, inconsistent results have been reported in environmental studies [21]. Therefore, the results indicate that different chemical and physical properties of soil should be considered during digestion of heavy metals of soil using partial digestion methods.

\subsection{Recommendation of digestion method}

The results in the present study show a significant correlation between the total digestion method (ISO-14869) and pseudo-total digestion (ISO 11466 and EPA 3050B) in all soils $(P<0.05)$. Silicate minerals are affected by the reaction of $\mathrm{HF}$ with $\mathrm{Si}$ to form the gaseous $\mathrm{SiF}_{4}$. $\mathrm{HClO}_{4}$ is a powerful oxidizer and dehydrating agent. The $\mathrm{HNO}_{3}$ is used to prevent the explosive reactions of the soil organic matter with $\mathrm{HClO}_{4}$ using in the ISO-14869 method. For $\mathrm{As}, \mathrm{Co}$ and $\mathrm{Pb}$, there is a very strong correlation $\left(R^{2}=1\right)$ between ISO-14869 and ISO-11466. For the rest of the elements, there was a high correlation between these two methods. The EPA3050B method showed high correlation for most of the elements by the ISO-14869 method, and for only the $\mathrm{Zn}$ element of this correlation was slightly low $\left(R^{2}=0.982\right)$. Based on QA/QC results, ISO11466 or Aqua regia can be used to analyze heavy metals in soil. However, the ISO-14869 method is a good method for baseline studies in soil, but it is good with the cost and volume of more consumed acid (Table 13). 
Table 12 Correlation coefficient $(r)$ of Pearson between chemical and physical properties of soil and percent recovery of heavy metals measured by EPA 3050B method

\begin{tabular}{|c|c|c|c|c|c|c|c|c|c|c|c|c|c|c|c|}
\hline Parameter & Clay (\%) & $\mathrm{OC}(\%)$ & $\mathrm{CaCO}_{3}(\%)$ & $\mathrm{pH}$ & $\mathrm{EC}$ & As & $\mathrm{Cd}$ & Co & $\mathrm{Cr}$ & $\mathrm{Cu}$ & $\mathrm{Mn}$ & $\mathrm{Ni}$ & $\mathrm{Pb}$ & V & $\mathrm{Zn}$ \\
\hline Clay (\%) & 1 & & & & & & & & & & & & & & \\
\hline OC (\%) & $0.64^{* *}$ & 1 & & & & & & & & & & & & & \\
\hline $\mathrm{CaCO}_{3}(\%)$ & $0.53^{*}$ & 0.20 & 1 & & & & & & & & & & & & \\
\hline $\mathrm{pH}$ & 0.26 & 0.24 & 0.38 & 1 & & & & & & & & & & & \\
\hline $\mathrm{EC}$ & -0.38 & -0.22 & -0.30 & $-0.86^{* *}$ & 1 & & & & & & & & & & \\
\hline As & -0.49 & -0.26 & -0.47 & -0.29 & 0.24 & 1 & & & & & & & & & \\
\hline $\mathrm{Cd}$ & -0.21 & -0.16 & 0.17 & 0.06 & 0.12 & 0.29 & 1 & & & & & & & & \\
\hline Co & 0.12 & 0.10 & -0.25 & -0.39 & 0.49 & 0.08 & -0.15 & 1 & & & & & & & \\
\hline $\mathrm{Cr}$ & $0.68^{* *}$ & $0.55^{*}$ & 0.26 & 0.16 & -0.37 & -0.02 & -0.30 & 0.03 & 1 & & & & & & \\
\hline $\mathrm{Cu}$ & 0.22 & 0.33 & -0.45 & -0.04 & 0.06 & -0.09 & -0.35 & 0.49 & 0.41 & 1 & & & & & \\
\hline $\mathrm{Mn}$ & 0.34 & 0.48 & 0.27 & 0.44 & -0.15 & -0.13 & 0.44 & -0.02 & 0.24 & 0.23 & 1 & & & & \\
\hline $\mathrm{Ni}$ & $-0.59^{*}$ & $-0.69^{* *}$ & -0.25 & -0.21 & 0.29 & 0.49 & 0.44 & -0.22 & -0.34 & -0.08 & -0.06 & 1 & & & \\
\hline $\mathrm{Pb}$ & -0.28 & -0.02 & -0.32 & -0.24 & 0.27 & $0.55^{*}$ & 0.40 & 0.13 & 0.18 & 0.35 & 0.18 & $0.52^{*}$ & 1 & & \\
\hline V & 0.43 & 0.19 & 0.43 & 0.05 & -0.11 & 0.10 & -0.001 & -0.12 & $0.57^{*}$ & 0.07 & 0.35 & 0.06 & 0.22 & 1 & \\
\hline $\mathrm{Zn}$ & -0.16 & 0.09 & -0.29 & $-0.57^{*}$ & $0.7^{* *}$ & 0.21 & 0.47 & 0.20 & -0.12 & 0.27 & 0.27 & 0.38 & $0.52^{*}$ & -0.04 & 1 \\
\hline
\end{tabular}

**Correlation is significant at the 0.01 level (2-tailed)

${ }^{*}$ Correlation is significant at the 0.05 level (2-tailed)

\section{Conclusions}

Concentration of heavy metals ( $\mathrm{As}, \mathrm{Cd}, \mathrm{Co}, \mathrm{Cr}, \mathrm{Cu}, \mathrm{Mn}, \mathrm{Ni}$, $\mathrm{Pb}, \mathrm{V}$ and $\mathrm{Zn}$ ) using ICP-OES and GFAAS and three methods of acid digestion with different acid composition (including $\mathrm{HNO}_{3}, \mathrm{HCl}, \mathrm{H}_{2} \mathrm{O}_{2}, \mathrm{HClO}_{4}$ and $\mathrm{HF}$ ) were measured in two reference materials and 15 soil samples. Using acid digestion methods is needed to quantify the amount of heavy metals in solid samples such as soils, sediments and sewage sludge. The use of quality control tools such as certified reference materials is a key factor to additional assures the accuracy of the results. This study specifies the importance of validating sample digestion methods using reference materials and soil samples before environmental analyzes. Using $\mathrm{HF}$ and $\mathrm{HClO}_{4}$ in the digestion process increases the extraction and recovery of heavy metals from the soil. However, using $\mathrm{HF}$ and $\mathrm{HClO}_{4}$ for routine analyzes is not recommended because the digestion process is hazardous and difficult, and also it is required to have certain laboratory equipment (for example, a washable perchloric hood) due to its high explosive potential and the corrosive nature of $\mathrm{HClO}_{4}$. For the digestion procedure, the extraction time and the total reagent consumption have significant importance. In ISO 14869-1, the amount of acid used is about $25 \mathrm{ml}$, considering the repeat steps, and about $6 \mathrm{~h}$ is required to complete the digestion. In EPA 3050B, the samples were extracted for 180-200 min including evaporation and cooling. Depending on the repetition of the $\mathrm{HNO}_{3}$ addition step, the reactant volume is different between 50 and $35 \mathrm{ml}$. In the ISO 11466 method, about
Table 13 Correlation of linear regression $(Y=X 0+a X)$ of heavy metal content by different digestion methods in the soils

\begin{tabular}{|c|c|c|c|c|}
\hline Y & Element (sample nos.) & $\begin{array}{l}a \text { (coef- } \\
\text { ficient } \\
\text { of } X \text { ) }\end{array}$ & $x_{0}$ & $\mathrm{R}^{2}$ \\
\hline \multirow[t]{2}{*}{ ISO-14869 } & \multirow[t]{2}{*}{ As $(n=15)$} & 1.02 & $16.5^{\mathrm{a}}$ & $1.00^{* *}$ \\
\hline & & 1.26 & $31.02^{b}$ & $0.99^{* *}$ \\
\hline \multirow[t]{2}{*}{ ISO-14869 } & \multirow[t]{2}{*}{$\mathrm{Cd}(n=15)$} & 1.14 & $0.058^{\mathrm{a}}$ & $0.998^{* *}$ \\
\hline & & 1.16 & $0.17^{\mathrm{b}}$ & $0.991^{* *}$ \\
\hline \multirow[t]{2}{*}{ ISO-14869 } & \multirow[t]{2}{*}{ Co $(n=15)$} & 1.04 & $2.27^{\mathrm{a}}$ & $1.00^{* *}$ \\
\hline & & 1.36 & $4.64^{b}$ & $1.00^{* *}$ \\
\hline \multirow[t]{2}{*}{ ISO-14869 } & \multirow[t]{2}{*}{$\mathrm{Cr}(n=15)$} & 1.03 & $12.49^{\mathrm{a}}$ & $0.994^{* *}$ \\
\hline & & 1.65 & $2.12^{\mathrm{b}}$ & $0.995^{* *}$ \\
\hline \multirow[t]{2}{*}{ ISO-14869 } & \multirow[t]{2}{*}{$\mathrm{Cu}(n=15)$} & 1.06 & $8.28^{\mathrm{a}}$ & $0.99^{* *}$ \\
\hline & & 1.25 & $5.95^{\mathrm{b}}$ & $0.977^{* *}$ \\
\hline \multirow[t]{2}{*}{ ISO-14869 } & \multirow[t]{2}{*}{$M n(n=15)$} & 1.05 & $24.96^{\mathrm{a}}$ & $0.996^{* *}$ \\
\hline & & 1.71 & $-92.97^{b}$ & $0.995^{* *}$ \\
\hline \multirow[t]{2}{*}{ ISO-14869 } & \multirow[t]{2}{*}{$\mathrm{Ni}(n=15)$} & 1.12 & $-3.87^{\mathrm{a}}$ & $0.999 * *$ \\
\hline & & 1.22 & $-6.65^{b}$ & $0.999 * *$ \\
\hline \multirow[t]{2}{*}{ ISO-14869 } & \multirow[t]{2}{*}{$\mathrm{Pb}(n=15)$} & 1.13 & $14.46^{\mathrm{a}}$ & $1.00^{* *}$ \\
\hline & & 1.13 & $67.59^{b}$ & $0.999 * *$ \\
\hline \multirow[t]{2}{*}{ ISO-14869 } & \multirow[t]{2}{*}{$\mathrm{V}(n=15)$} & 1.09 & $5.66^{\mathrm{a}}$ & $0.995^{* *}$ \\
\hline & & 1.66 & $1.27^{\mathrm{b}}$ & $0.966^{* *}$ \\
\hline \multirow[t]{2}{*}{ ISO-14869 } & \multirow[t]{2}{*}{$\mathrm{Zn}(n=15)$} & 1.34 & $-42.80^{\mathrm{a}}$ & $0.997^{* *}$ \\
\hline & & 1.95 & $-59.63^{b}$ & $0.982^{* *}$ \\
\hline
\end{tabular}

${ }^{* *}$ Correlation is significant at the 0.01 level $(P<0.01)$

${ }^{\mathrm{a}}(X=$ the ISO 11466 method $)$

${ }^{\mathrm{b}}(X=$ the EPA $3050 \mathrm{~B}$ method $)$ 
$19 \mathrm{~h}$ is required to complete the digestion process with a 16-h start-up time and the volume of the used reagent is $28 \mathrm{ml}$. Depending on the elements studied, the digestion method should be selected according to the recovery results in the reference material and the results of the natural samples. The low extraction efficiency for some elements is likely caused by binding the metals with silicate clays in the soil, which is extracted lower by the acids used in these two methods. In this study, the ISO 11466 or Aqua regia method will be considered as a suitable method considering all factors such as extraction efficiency, the amount of used acid and the required equipment in reference samples and calcareous soils, if digestion of all the elements is not required. The Aqua regia method is a suitable method for routine analysis, which is not required to use expensive tools and devices such as platinum tubes, PTFE digestion tubes or digestion bombs, and other special tools compared to other digestive methods like using $\mathrm{HClO}_{4}$ and HF. In high-lime soils, adding Aqua regia solution, high foaming causes problem that will be eliminated by adding additional $\mathrm{HNO}_{3}$ before the heat treatment begins. The results showed that lime in calcareous soils does not affect the recovery of elements. Also, the results showed that there is a positive and significant correlation between the measured heavy elements, indicating that most of the elements in the structure of minerals are geologically located.

Acknowledgements The authors would like to thank the Iranian Soil and Water Research Institute (WSRI) partially and financially supporting this research. This study was funded by Iranian Soil and Water Research Institute (WSRI) (Grant Number 2-10-10-94108). Also, we thank the technical staff of laboratories department of Soil and Water Research Institute of Iran for the assistance during the experiments and Miss. Neda Baharlou, Mrs. Shida Tabakhian and Mrs. Fatemeh Mansouri for their guidance to set up the experimental methods.

\section{Compliance with ethical standards}

Conflict of interest The authors declare that they have no conflict of interest.

\section{References}

1. Adamo P, Arienzo M, Bianco M, Terribile F, Violante P (2002) Heavy metal contamination of the soils used for stocking raw materials in the former ILVA iron-steel industrial plant of Bagnoli (southern Italy). Sci Total Environ 295:17-34. https://doi. org/10.1016/S0048-9697(02)00020-7

2. Alloway BJ (2013) Molybdenum, heavy metals in soils. Springer, New York, pp 527-534. https://doi. org/10.1007/978-94-007-4470-7_21

3. Al-Bakheet SA, Attafi IM, Maayah ZH, Abd-Allah AR, Asiri YA, Korashy HM (2013) Effect of long-term human exposure to environmental heavy metals on the expression of detoxification and DNA repair genes. Environ Pollut 181:226-232
4. Ávan den Akker AH, Delft W (1991) Comparison of microwave and conventional extraction techniques for the determination of metals in soil, sediment and sludge samples by atomic spectrometry. Analyst 116:347-351. https://doi.org/10.1039/ AN9911600347

5. Berrow ML, Stein WM (1983) Extraction of metals from soils and sewage sludges by refluxing with aqua regia. Analyst 108:277-285. https://doi.org/10.1039/AN9830800277

6. Atari M, Dabiri R, Fazlvalipour MA (2015) Environmental impacts of mining on soil resources of the Ferdows Plain, Northwest of Sabzevar. In: The 2nd National conference on carbrode studies in chemistry, University of Tehran, pp 805813 (in Persian)

7. Bettinelli M, Beone G, Spezia S, Baffi C (2000) Determination of heavy metals in soils and sediments by microwave-assisted digestion and inductively coupled plasma optical emission spectrometry analysis. Anal Chim Acta 424:289-296. https:// doi.org/10.1016/S0003-2670(00)01123-5

8. Behbahaninia A, Farahani M (2016) Investigation of natural sources contamination with arsenic in the suburbs of Hashtrood city. East Azerbayjan Province, Environmental science and technology 2:27-35 (In Persian)

9. Bouyoucos GJ (1962) Hydrometer method improved for making particle size analyses of soils 1. Agron J 54:464-465. https://doi. org/10.2134/agronj1962.00021962005400050028x

10. Chatterjee A, Banerjee R (1999) Determination of lead and other metals in a residential area of greater Calcutta. Sci Total Environ 227:175-185. https://doi.org/10.1016/S0048-9697(99)00026-1

11. Chen M, Ma LQ (2001) Comparison of three aqua regia digestion methods for twenty Florida soils. Soil Sci Soc Am J 65:491-499. https://doi.org/10.2136/sssaj2001.652491x

12. De Abreu M, Berton R, De Andrade J (1996) Comparison of methods to evaluate heavy metals in organic wastes. Commun Soil Sci Plant Anal 27:1125-1135. https://doi.org/10.1080/00103 629609369621

13. Gaudino $S$, Galas $C$, Belli $M$, Barbizzi $S$, de Zorzi $P$, Jaćimović $R$, Jeran Z, Pati A, Sansone U (2007) The role of different soil sample digestion methods on trace elements analysis: a comparison of ICP-MS and INAA measurement results. Accredit Qual Assur 12:84-93. https://doi.org/10.1007/s00769-006-0238-1

14. Gee G, Bauder J (1979) Particle size analysis by hydrometer: a simplified method for routine textural analysis and a sensitivity test of measurement parameters 1. Soil Sci Soc Am J 43:10041007. https://doi.org/10.2136/sssaj 1979.036159950043000 50038x

15. Güven D, Akinci G (2011) Comparison of acid digestion techniques to determine heavy metals in sediment and soil samples. Gazi Univ J Sci 24:29-34

16. Hossner $L$ (1996) Dissolution for total elemental analysis. Methods of soil analysis Part 3-Chemical methods, pp 49-64

17. Hseu Z-Y, Chen Z-S, Tsai C-C, Tsui C-C, Cheng S-F, Liu C-L, Lin H-T (2002) Digestion methods for total heavy metals in sediments and soils. Water Air Soil Pollut 141:189-205. https://doi. org/10.1023/A:1021302405128

18. Institute SAS (1982) SAS user's guide: statistics. SAS Institute, Cary

19. Iso D (1995) Soil quality-extraction of trace elements soluble in aqua regia. International standard. Zagreb Croatia Croatian Standards Institute, Zagreb

20. ISO (2001) Soil quality e dissolution for the determination of total element content e part 1: dissolution with hydrofluoric and perchloric acids, ISO 14869-1, pp 1-5

21. Jakubowska M, Zembrzuski W, Lukaszewski Z (2006) Oxidative extraction versus total decomposition of soil in the determination of thallium. Talanta 68:1736-1739. https://doi. org/10.1016/j.talanta.2005.08.035 
22. Kaasalainen M, Yli-Halla M (2003) Use of sequential extraction to assess metal partitioning in soils. Environ Pollut 126:225233. https://doi.org/10.1016/S0269-7491(03)00191-X

23. Kalbitz K, Wennrich R (1998) Mobilization of heavy metals and arsenic in polluted wetland soils and its dependence on dissolved organic matter. Sci Total Environ 209:27-39. https:// doi.org/10.1016/S0048-9697(97)00302-1

24. Khorasanipour M, Esmaeilzadeh E (2015) Geo-genic arsenic contamination in the Kerman Cenozoic Magmatic Arc, Kerman, Iran: implications for the source identification and regional analysis. Appl Geochem 63:610-622. https://doi. org/10.1016/j.apgeochem.2015.08.004

25. Krause P, Erbslöh B, Niedergesäß R, Pepelnik R, Prange A (1995) Comparative study of different digestion procedures using supplementary analytical methods for multielement-screening of more than 50 elements in sediments of the river Elbe. Fresenius' J Anal Chem 353:3-11. https://doi.org/10.1007/ BF00322882

26. Lorentzen EM, Kingston HS (1996) Comparison of microwaveassisted and conventional leaching using EPA method 3050B. Anal Chem 68:4316-4320. https://doi.org/10.1021/ac960553|

27. Loeppert RH, Suarez DL (1996) Carbonate and gypsum

28. Manz M, Weissflog L, Kühne R, Schüürmann G (1999) Ecotoxicological hazard and risk assessment of heavy metal contents in agricultural soils of central Germany. Ecotoxicol Environ Saf 42:191-201. https://doi.org/10.1006/eesa.1998.1741

29. Marin B, Chopin E, Jupinet B, Gauthier D (2008) Comparison of microwave-assisted digestion procedures for total trace element content determination in calcareous soils. Talanta 77:282-288. https://doi.org/10.1016/j.talanta.2008.06.023

30. Marr IL, Kluge P, Main L, Margerin V, Lescop C (1995) Digests or extracts?-Some interesting but conflicting results for three widely differing polluted sediment samples. Microchim Acta 119:219-232. https://doi.org/10.1007/BF01244001

31. Martin C (1997) Heavy metal concentrations in floodplain surface soils, Lahn River, Germany. Environ Geol 30:119-125. https ://doi.org/10.1007/s002540050139

32. Masouri S, Motahar M (2015) Geology and evaluation of lead and Zinc deposits, Case study of Anguran deposit. In: The 2nd National conference lead and zinc, Iran, pp 500-511 (In Persian)

33. McGrath D (1998) Use of microwave digestion for estimation of heavy metal content of soils in a geochemical survey. Talanta 46:439-448. https://doi.org/10.1016/S0039-9140(97)00400-1

34. McLean JE, Bledsoe BE, Sourcebook EEA (1992) Behavior of metals in soils. EPA Environmental Assessment Sourcebook, pp 19-56

35. Melaku S, Dams R, Moens L (2005) Determination of trace elements in agricultural soil samples by inductively coupled plasma-mass spectrometry: microwave acid digestion versus aqua regia extraction. Anal Chim Acta 543:117-123. https:// doi.org/10.1016/j.aca.2005.04.055

36. Navarro P, Raposo J, Arana G, Etxebarria N (2006) Optimisation of microwave assisted digestion of sediments and determination of Sn and Hg. Anal Chim Acta 566:37-44. https://doi. org/10.1016/j.aca.2006.02.056

37. Niskavaara H, Reimann C, Chekushin V, Kashulina G (1997) Seasonal variability of total and easily leachable element contents in topsoils $(0-5 \mathrm{~cm})$ from eight catchments in the European Arctic (Finland, Norway and Russia). Environ Pollut 96:261-274. https://doi.org/10.1016/S0269-7491(97)00031-6

38. Peña-Icart M, Tagle MEV, Alonso-Hernández $C$, Hernández JR, Behar M, Alfonso MSP (2011) Comparative study of digestion methods EPA 3050B $\left(\mathrm{HNO}_{3}-\mathrm{H}_{2} \mathrm{O}_{2}-\mathrm{HCl}\right)$ and ISO 11466.3 (aqua regia) for $\mathrm{Cu}, \mathrm{Ni}$ and $\mathrm{Pb}$ contamination assessment in marine sediments. Marine Environ Res 72:60-66. https://doi. org/10.1016/j.marenvres.2011.05.005
39. Pietrzak U, McPhail D (2004) Copper accumulation, distribution and fractionation in vineyard soils of Victoria, Australia. Geoderma 122:151-166. https://doi.org/10.1016/j.geode rma.2004.01.005

40. Safari N, Delavar MA, Esfandiarpor Bojeni A, Salehi M, Oliaei $H$ (2017) Mapping the overall soil pollution by heavy metals using limitation scores. J Soil Manag Sustain 6(4):55-70 (In Persian)

41. Sandroni V, Smith CM (2002) Microwave digestion of sludge, soil and sediment samples for metal analysis by inductively coupled plasma-atomic emission spectrometry. Anal Chim Acta 468:335-344. https://doi.org/10.1016/S0003 -2670(02)00655-4

42. Sandroni V, Smith CM, Donovan A (2003) Microwave digestion of sediment, soils and urban particulate matter for trace metal analysis. Talanta 60:715-723. https://doi.org/10.1016/S0039 -9140(03)00131-0

43. Sastre J, Sahuquillo A, Vidal M, Rauret G (2002) Determination of $\mathrm{Cd}, \mathrm{Cu}, \mathrm{Pb}$ and $\mathrm{Zn}$ in environmental samples: microwaveassisted total digestion versus aqua regia and nitric acid extraction. Anal Chim Acta 462:59-72. https://doi.org/10.1016/S0003 -2670(02)00307-0

44. Sawhney B, Stilwell D (1994) Dissolution and elemental analysis of minerals, soils and environmental samples. Quant Methods Soil Mineral 49-82

45. Ščančar J, Milačič R, Horvat M (2000) Comparison of various digestion and extraction procedures in analysis of heavy metals in sediments. Water Air Soil Pollut 118:87-99. https://doi. org/10.1023/A:1005187602820

46. Siaka M, Owens C, Birch G (1998) Evaluation of some digestion methods for the determination of heavy metals in sediment samples by flame-AAS. Anal Lett 31:703-718. https://doi. org/10.1080/00032719808001873

47. Sims J, Igo E, Skeans Y (1991) Comparison of routine soil tests and EPA method 3050 as extractants for heavy metals in Delaware soils. Commun Soil Sci Plant Anal 22:1031-1045. https:// doi.org/10.1080/00103629109368472

48. Sneddon J, Hardaway C, Bobbadi KK, Reddy AK (2006) Sample preparation of solid samples for metal determination by atomic spectroscopy -an overview and selected recent applications. Appl Spectrosc Rev 41:1-14. https://doi.org/10.1080/05704 920500385445

49. Sukkariyah BF, Evanylo G, Zelazny L, Chaney RL (2005) Recovery and distribution of biosolids-derived trace metals in a clay loam soil. J Environ Qual 34:1843-1850. https://doi.org/10.2134/jeq20 04.0180

50. Sun $Y-C$, Chi P-H, Shiue $M-Y$ (2001) Comparison of different digestion methods for total decomposition of siliceous and organic environmental samples. Anal Sci 17:1395-1399. https ://doi.org/10.2116/analsci.17.1395

51. Száková J, Miholová D, Tlustoš P, Šestáková I, Frková Z (2010) Effect of soil properties and sample preparation on extractable and soluble $\mathrm{Pb}$ and Cd fractions in soils. Agric Sci 1:119. https:// doi.org/10.4236/as.2010.13015

52. Tam N, Yao M (1999) Three digestion methods to determine concentrations of $\mathrm{Cu}, \mathrm{Zn}, \mathrm{Cd}, \mathrm{Ni}, \mathrm{Pb}, \mathrm{Cr}, \mathrm{Mn}$, and $\mathrm{Fe}$ in mangrove sediments from Sai Keng, Chek Keng, and Sha Tau Kok, Hong Kong. Bull Environ Contam Toxicol 62:708-716. https://doi. org/10.1007/s001289900931

53. Taraškevičius R, Zinkutè R, Čyžius GJ, Kaminskas M, Jankauskaitė $M$ (2013) Soil contamination in one of preschools influenced by metal working industry. In: Environment, technology, resources: proceedings of the 9th international scientific and practical conference, June 20-22, 2013, Rezekne, pp 83-86

54. Twyman R (2005) Sample dissolution for elemental analysis. Wet Digestion 
55. USEPA (1996) Acid digestion of sludges, solids and soils, USEPA 3050B, In SW-846 Pt 1. Office of Solid and Hazardous Wastes, USEPA, Cincinnati

56. Vercoutere K, Fortunati U, Muntau H, Griepink B, Maier EA (1995) The certified reference materials CRM 142 R light sandy soil, CRM 143 R sewage sludge amended soil and CRM 145 R sewage sludge for quality control in monitoring environmental and soil pollution. Fresenius' J Anal Chem 352:197-202. https://doi. org/10.1007/BF00322326

57. Walkley A, Black IA (1934) An examination of the Degtjareff method for determining soil organic matter, and a proposed modification of the chromic acid titration method. Soil Sci 37:29-38

58. Yari Y, Momtaz H, Taheri M (2017) Spatial distribution of some heavy metals in soils of Zanjan industrial. Sci Water Soil 26:223236 (in Persian)

Publisher's Note Springer Nature remains neutral with regard to jurisdictional claims in published maps and institutional affiliations. 